DOI: 10.32089/WBH.PHW.2019.3(269).0003

orcid.org/0000-0002-7902-5424

\title{
MARCIN KACZKOWSKI \\ Problem oceny taktyki i dowodzenia w bitwie jutlandzkiej (1916)
}

Bitwa jutlandzka należy do największych bitew morskich wszechczasów. Stanowiła punkt kulminacyjny niemiecko-brytyjskiego wyścigu zbrojeń poprzedzającego I wojnę światową oraz samej wojny na morzu w latach 1914-1918. Stała się swoistym sprawdzianem dla ówczesnej techniki, taktyki, sztuki operacyjnej a także wyszkolenia oraz załóg i dowódców obydwu wrogich marynarek wojennych. $\mathrm{Z}$ tego względu, a także $\mathrm{z}$ powodu iście epickiego rozmachu starcia, od początku budziła liczne kontrowersje1. Mimo że nie zmieniła ona faktycznej równowagi sił, jej znaczenie w historii wojen na morzu jest niezaprzeczalne. Wnioski wyciągnięte $z$ bitwy jutlandzkiej miały znaczący wpływ na rozwój flot wojennych oraz doktryn po I wojnie światowej.

Jedną z najbardziej kontrowersyjnych kwestii związanych z bitwą jutlandzką jest dowodzenie oraz kluczowe decyzje podejmowane przez dowódców obu flot, jak również przyjęta przez nich taktyka. Krótko po bitwie rozgorzały na ten temat zażarte dyskusje, zwłaszcza wśród brytyjskich oficerów. Były one kontynuowane także po zakończeniu wojny, gdy na światło dzienne wychodziły kolejne fakty na temat przebiegu bitwy. Szczególnie zaciekłe spory prowadzono w Wielkiej Brytanii, gdzie ścierali się ze sobą krytycy głównodowodzącego flotą admirała Johna Jellicoe z jego obrońcami. To właśnie decyzje dowódcy Grand Fleet ${ }^{2}$ spotkały się z najpoważniejszą

C. Bellairs, The Battle of Jutland; The Sowing and the Reaping, London 1919; R. Bacon, The Jutland Scandal, London 1925; J. Harper, The Truth about Jutland, London 1927; W. Churchill, The Worlds Crisis 1916-1918, t. 2, London 1927; L. Gibson, J. Harper, The Riddle of Jutland: An Authentic History, New York 1934; W. Schliehauf, ed., with Stephen McLaughlin, Jutland: The Naval Staff Appreciation, Barnsley 2016.

2 Grand Fleet (pol. Wielka Flota) główne zgrupowanie operacyjno-strategiczne Royal Navy w czasie I wojny światowej. Stacjonowało w Scapa Flow, chociaż część również stacjonowała 
krytyką ze strony części kadry oficerskiej Royal Navy. Trudno się temu dziwić, jako że dysponując silniejszą flotą miał większą możliwość uchwycenia inicjatywy, tymczasem właśnie jego ostrożność wywarła wpływ na przebieg, a także rezultaty starcia - dla Brytyjczyków rozczarowujące - i to właśnie jego postępowanie zaważyło na ostatecznym wyniku bitwy.

Po wojnie dowództwo marynarki wojennej zleciło opracowanie oficjalnej analizy bitwy. Praca ta została pierwotnie powierzona kontradmirałowi Johnowi Harperowi. Dokument ten (znany jako Harpers Record) miał bazować na dostępnych materiałach marynarki wojennej i ukazywać obraz bitwy bez komentarza. Jednakże w międzyczasie komandor Carlyon Ballairs z własnej inicjatywy sporządził i opublikował w 1919 r. analizę bitwy pod tytułem The Battle of Jutland, The Swing and Reading. Atakował w niej adm. Jellicoe, jednocześnie chwaląc postawę wiceadmirała Davida Beatty'ego (dowódcy zespołu brytyjskich krążowników liniowych)3. Tymczasem Harper w swojej pracy krytykował postawę Beatty'ego oraz wytykał mu liczne błędy. W 1919 r. na stanowisku pierwszego lorda morskiego admirała Rosslyna Weymyssa zastąpił admirał Beatty. Nie dopuścił on do publikacji krytycznego wobec niego raportu Harpera. Zamiast tego polecił opracować nową analizę bitwy jutlandzkiej, powierzając to zadanie braciom Kennethowi i Alfredowi Dewarom (obaj w stopniu komandora). Zaliczali się oni do zwolenników Beatty’ego, co - jak wkrótce się okazało - wpłynęło na końcowy efekt ich pracy. Na początku 1922 r. ukończone zostało ich dzieło - Naval Staff Appreciation of Jutland. Było ono przepełnione krytyką Jellicoe i jego dowodzenia, praktycznie obwiniając go o zaprzepaszczenie szansy na decydujące zwycięstwo. Po zapoznaniu się z tekstem oficjalny historyk Royal Navy Julian Corbett stwierdził, iż Dewarowie często rozmijali się z faktami lub je nadinterpretowywali'. Admiralicja uznała krytykę Jellicoe w Naval Staff Appreciation za zbyt daleko posuniętą i nie zdecydowała się na publikację oryginalnego dokumentu. Dopiero w 1924 r. opublikowany został przeredagowany i okrojony tekst jako The Narrative of the Battle of Jutland. Julian Corbett sporządził pierwszy dosyć obiektywny opis bitwy w swojej oficjalnej historii Royal Navy w czasie I wojny światowej (History of the Great War Naval Operations, Based on Official Documents) wydanej w trzech tomach między 1920 a 1923 r. ${ }^{5}$ Bitwę jutlandzką opisał także Winston Churchill w swojej historii I wojny światowej zatytułowanej

na kotwicowisku w Zatoce Cromarty (Cromarty Firth), natomiast Flota Krążowników Liniowych w Rosyth. W jego skład wchodziły wszystkie brytyjskie drednoty z wyjątkiem samego HMS Dreadnought, który został przeniesiony do Chanel Fleet.

3 C. Bellairs, The Battle of Jutland..., s. IX-XII.

$4 \quad$ W. Schliehauf, Jutland: The Naval..., s. 12.

5 J. Corbett, Naval Operations, t. 3, London 1923, s. 326. 
The Word Crisis. Jego opis, chociaż bardziej obiektywny niż Dewarów, faworyzuje Beatty'ego ${ }^{6}$. Trudno się temu dziwić biorąc pod uwagę, że w czasie gdy zajmował stanowisko Pierwszego Lorda Admiralicji (w latach 1911-1915), Churchill promował Beatty’ego i darzył go sporym zaufaniem7. W 1925 r. wiceadmirał Reginald Bacon opublikował swoje spojrzenie na jutlandzkie kontrowersje, zatytułowane - The Jutland Scandal. Bacon mocno skrytykował "analizę" Deware'ów, stając w obronie admirała Jellicoe i jego decyzji. Krytyką objął również udział Beatty’ego w bitwie, zarzucając mu wiele poważnych błędów i zaniedbań ${ }^{8}$. Dwa lata później ukazała się praca zatytułowana The Truth abort Jutland autorstwa kadm. Harpera, utrzymana w podobnym tonie. Bronił on admirała Jellicoe, jednocześnie krytykując Beatty’ego oraz zwracając uwagę na problemy systemowe w brytyjskiej marynarce wojennej ${ }^{9}$.

Dyskusje na ten temat toczą się do dziś w kręgach oficerskich marynarek wojennych całego świata (przede wszystkim brytyjskiej), jak również specjalistycznej prasie i dotąd nikomu nie udało się przedstawić jednej ostatecznej konkluzji, która zadowoliłaby wszystkie strony sporu ${ }^{10}$.

Krytycy adm. Jellicoe zarzucają mu, że przez zbytnią ostrożność wypuścił z rąk najlepszą okazję do zniszczenia Hochseeflotte. Natomiast jego obrońcy argumentują, iż ostrożność była uzasadniona w związku z trudnymi warunkami wynikającymi z pogody (słaba widzialność) oraz problemów $\mathrm{z}$ komunikacją w Grand Fleet. Udało mu się zmusić przeciwnika do odwrotu, nie ponosząc zbyt dużych strat i zachowując status quo, co było korzystne dla Brytyjczyków.

Kwestie te, jakkolwiek obecne w polskiej literaturze przedmiotu, w tym w syntezach ${ }^{11}$, nie były jednak przedmiotem pogłębionej analizy. Zamiarem

6 W. Churchill, The Worlds Crisis 1911-1918, London 2007, s. 26.

7 A. Gordon, The rules of the game. Jutland and British Naval Command, New York 2013, s. $553-555$.

8 J. Harper, R. Bacon, The Jutland Scandal, The Truth about the First World War's Greatest Sea Battle, New York 2016, s. 9-13.

9 Ibidem, s. 12-16.

10 Jednym z najlepszych przykładów wciąż żywej dyskusji na temat bitwy jutlandzkiej jest książka autorstwa wnuka admirała Jellicoe, która ukazała się w setną rocznicę bitwy. Już sam tytuł jest niezwykle wymowny. N. Jellicoe, Jutland: The Unfinished Battle; A Personal History of a Naval Controversy, Annapolis 2016. Autorzy innych ważnych pozycji dotyczących starcia również mają różne zdania na niektóre kontrowersyjne tematy; zob. A. Gordon, The rules of the game...; J. Brooks, Dreadnougth Gunnery and the Battle of Jutland: The Question of Fire Control, London 2005; N. J. M. Campbell, Jutland: The Analysys of the Fighting, New York 2000.

11 J. Gozdawa-Gołębiowski, T. Wywerka Prekurat, Pierwsza wojna światowa na morzu, Warszawa 1997, s. 287; Z. Flisowski, Bitwa jutlandzka 1916, Warszawa 1994; T. Klimczyk, Największe starcie pancerników. Bitwa Jutlandzka, Warszawa 2007. 
autora jest podjęcie stosownej próby prześledzenia najważniejszych wątków związanych z dowodzeniem i taktyką zastosowaną w czasie bitwy jutlandzkiej. Rzecz jasna przeanalizowane zostanie nie tylko dowodzenie i decyzje adm. Jellicoe, ale również wszystkich pozostałych kluczowych dla przebiegu tej bitwy postaci po obu stronach czyli: wiceadmirała Davida Beatty'ego dowódcy Zespołu Krążowników Liniowych ${ }^{12}$, wiceadmirała Reinharda Scheera głównodowodzącego Hochseeflotte ${ }^{13}$ i kontradmirała Franza Hippera dowódcy 1 Grupy Rozpoznawczej (I. Aufklärungsgruppe - niemieckich krążowników liniowych).

\section{Brytyjczycy}

Należałoby zacząć od analizy taktyki i dowodzenia po stronie brytyjskiej, jako że wzbudzają one do dziś największe kontrowersje wśród komentatorów. Przed wybuchem I wojny światowej Royal Navy przez prawie 100 lat niepodzielnie panowała na morzach. Jednocześnie przez cały ten czas nie znalazła godnego rywala i nie stoczyła większej bitwy z równoważnym przeciwnikiem ${ }^{14}$. W związku z tym brytyjscy oficerowie wciąż odwoływali się do istniejącej tradycji - wielkich dowódców z czasów wojen napoleońskich i XVIII w. Dla wielu oficerów Royal Navy najlepszym wzorem dowódcy był admirał sir Horatio Nelson, bohater wojen napoleońskich, uznawany za jednego z największych brytyjskich admirałów ${ }^{15}$. Gdy przystąpiono do analizy bitwy jutlandzkiej, natychmiast pojawiły się porównania z innymi słynnymi bitwami Royal Navy. Najczęściej przywoływano rzecz jasna Trafalgar, ze względu na pewne podobieństwa, jakie dostrzegali niektórzy komentatorzy, ale także na zupełnie różny wynik pomimo odmiennego stosunku sił ${ }^{16}$. Przy czym wielu z tych - którzy czynili owe porównania zdawało się zapominać, jak wielkie zmiany zaszły w realiach wojny morskiej oraz sytuacji międzynarodowej. Tak oto ostrożność i zachowawczość

12 Flota (Zespół) Krążowników Liniowych (ang. Battle Cruiser Fleet) - sformowany na początku 1915 r. zespół grupujący brytyjskie krążowniki liniowe oraz towarzyszące im eskadry krążowników lekkich i flotylle niszczycieli (zob. Ordre de Bataille), którego podstawowym zadaniem było szybkie reagowanie w razie ataków na brytyjskie nadbrzeżne miasta. Stacjonował w Rosyth pod dowództwem wadm. D. Beatty'ego. Podporządkowany głównodowodzącemu Grand Fleet.

13 Hochseeflotte (pol. Flota Pełnomorska) - niemiecka flota liniowa, grupująca wszystkie nowoczesne okręty liniowe (wszystkie drednoty, krążowniki liniowe za wyjątkiem SMS Goebena odciętego na Morzu Czarnym oraz najnowsze tzw. predrednoty).

14 Ibidem, s. 421.

15 A. Gordon, The rules of the game..., s. 348-354.

16 G. Bennett, Jutlandia 1916: Bitwa morska, Warszawa 2010, s. 248. 
Jellicoe została przeciwstawiona agresywności i dążeniu do rozstrzygającego zwycięstwa Nelsona.

Aby podjąć się oceny Jellicoe i jego dowodzenia w bitwie jutlandzkiej, należałoby najpierw prześledzić jego kluczowe decyzje, które zaważyły na przebiegu starcia. Nie można przy tym pominąć okoliczności, w jakich były one podejmowane, obrazu sytuacji, jakim w tamtym czasie dysponował głównodowodzący Grand Fleet i jego pierwotnego planu bitwy, którym się kierował. Trzeba też odpowiedzieć na pytanie, co Jellicoe stawiał sobie za najważniejszy cel w przypadku starcia z Hochseeflotte i jak w jego oczach starcie to mogło wpłynąć na przebieg całej wojny. Bez tej wiedzy nie da się zrozumieć jego toku myślenia, który miał wpływ na podjęte decyzje, a co za tym idzie na przebieg bitwy.

Plan bitwy zakładał wykorzystanie Floty Krążowników Liniowych do naprowadzenia Hochseeflotte na główne siły Grand Fleet. Te zaś dysponując przewagą liczebną miały zadać Niemcom jak największe straty. $Z$ takimi założeniami Beatty i Jellicoe opuścili swoje bazy 30 maja 1916 r. Jako pierwsza kontakt z nieprzyjacielem nawiązała Flota Krążowników Liniowych i w początkowej fazie bitwy samotnie zmagała się z przeciwnikiem. Jellicoe nie miał żadnego wpływu na przebieg tej fazy starcia, mógł jedynie liczyć na to, że wadm. Beatty wykona swoje zadanie. Na ocenę działań tego ostatniego przyjdzie jeszcze czas. Jellicoe w tym czasie prowadził główne siły Grand Fleet na południe, starając się na podstawie meldunków od Beatty’ego i Room $40^{17}$ ustalić pozycje Hochseeflotte i samemu zająć dogodną pozycję do zastawienia pułapki. Pierwsza bardzo ważna decyzja Jellicoe dotyczyła momentu i sposobu rozwinięcia floty z szyku marszowego w szyk bojowy.

Kwestia rozwinięcia floty była poruszana zaraz po bitwie przez niektórych dowódców eskadr bojowych Grand Fleet. Zarzucali oni swojemu przełożonemu, iż rozwinął flotę w nieoptymalny sposób. Później opinię tę podchwycili inni komentatorzy bitwy ${ }^{18}$. Jellicoe miał dwie możliwości: rozwinąć flotę na lewą (SW południowo-zachodnią) lub na prawą burtę (SE południowo-wschodnią). Rozwinięcie na prawą burtę oznaczałoby, że flota brytyjska poruszałaby się w kierunku floty niemieckiej. Obie floty szłyby wtedy kursem na spotkanie, tak więc kontakt bojowy nastąpiłby wcześniej,

17 Room 40 był komórką dekryptażu Royal Navy. Brytyjczycy znali szyfry Kaiserliche Marine m.in. dzięki przejęciu przez Rosjan ksiąg kodowych z wraku krążownika SMS Magdeburg, który w sierpniu 1914 r. wszedł na skały u wybrzeży Estonii. Rosjanie przekazali następnie niemieckie księgi kodowe Brytyjczykom. Dzięki temu Room 40 mógł na bieżąco odszyfrowywać przechwycone niemieckie komunikaty i przesyłać je do admiralicji lub do dowódców flot. J. Gozdawa-Gołębiowski, T. Wywerka Prekurat, Pierwsza wojna..., s. 137; A. Gordon, The rules of the game..., s. 223-225; C. London, Jutland 1916 Clash of the Dreadnoughts, Botley - Oxford 2000, s. 20.

18 C. Bellairs, The Battle of Jutland..., s. 149-155; W. Schliehauf, Jutland: The Naval..., s. 117. 
zaś odległość szybko by malała ${ }^{19}$. Oznaczałoby to, iż Niemcom trudniej byłoby zerwać kontakt i wykonać odwrót. Część komentatorów uznała takie rozwiązanie za lepsze i dające większą szansę na zadanie Hochseeflotte decydującego uderzenia lub przynajmniej poważnych strat ${ }^{20}$. Jellicoe jednak tłumaczył, że rozwiązanie takie uznał za zbyt ryzykowne. Po pierwsze, w sytuacji rozwinięcia na prawą burtę na czele szyku liniowego znalazłaby się 1 Eskadra Pancerników (1 Battle Squadron) wiceadmirała Cecila Burneya, składająca się głównie ze starszych i słabszych drednotów ${ }^{21}$. Dodatkowo doszłoby do bitwy spotkaniowej, w której floty poruszałyby się w przeciwnych kierunkach. Poszczególne eskadry wchodziłyby więc kolejno do walki, co na początku zniwelowałoby przewagę liczebną Brytyjczyków. 1 Eskadra Pancerników natknęłaby się w pierwszej kolejności na niemiecką 3 Eskadrę Pancerników (III Geschwader), składającą się z najnowocześniejszych drednotów. Podsumowując, manewr taki wiązał się ze sporym ryzykiem, którego Jellicoe wolał uniknąć. Jeżeli dodać do tego kwestie techniczne (nieskuteczne pociski przeciwpancerne, niższa szybkostrzelność, problemy z materiałami miotającymi - kordyt), Brytyjczycy najprawdopodobniej musieliby liczyć się z poważnymi stratami. Część oficerów (zwłaszcza blisko związanych $\mathrm{z}$ admirałem Beattym) była gotowa ponieść takie straty, jeżeli tylko oznaczałoby to zniszczenie wrogiej floty. Jednakże dzięki informacjom, jakimi dzisiaj dysponujemy, można stwierdzić, że wynik takiego starcia nie musiał być wcale jednoznacznie korzystny dla Brytyjczyków.

Można przyjąć, że brytyjski głównodowodzący preferował podjęcie walki z niemiecką flotą na równoległych kursach, nie zaś na kontrkursach ${ }^{22}$. Chęć uniknięcia starcia na kontrkursach była prawdopodobnie kolejną przyczyną, dla której zdecydował o rozwinięciu floty na lewą, nie zaś na prawą burtę.

Teoretycznie Jellicoe miał również trzecią możliwość. Rozwinięcie floty jednocześnie na obie burty, a co za tym idzie jej podział i oskrzydlenie Niemców z dwóch stron. Zwolennikiem takiego rozwiązania był między innymi wiceadmirał Doveton Sturdee, dowódca 4 Eskadry Pancerników ${ }^{23}$. Przed wojną prowadzone były badania nad możliwością zastosowania tak zwanej taktyki podzielonej lub dywizjonowej (divisional tactics). Przeprowadzone zostały nawet manewry dowodzące teoretycznej użyteczności takiej bardziej elastycznej - taktyki. Jellicoe zaakceptował istnienie owej opcji, lecz

\footnotetext{
19 G. Bennett, Jutlandia..., s. 214.

20 Ibidem, s. 122.

21 Z. Flisowski, Bitwa jutlandzka..., s. 136. Drednot (od ang. Dreadnought) - określenie generacji pancerników powstałej po wprowadzeniu do służby we flocie brytyjskiej HMS Dreadnought (1906).

22 Ibidem, s. 124.

23 G. Bennett, Jutlandia..., s. 215.
} 
nie zakładał możliwości walki z Hochseeflotte inaczej niż całą flotą, rozwiniętą w pojedynczy szyk liniowy ${ }^{24}$. Wprawdzie pojawił się sygnał 13 - oznaczający rozkaz do podjęcia samodzielnych działań przez dowódców poszczególnych eskadr, jednakże wciąż mieli oni kierować się wytycznymi głównodowodzącego. Można snuć rozważania, jaki obrót przybrałyby wydarzenia, gdyby 1 i 5 eskadry pancerników zostały rozwinięte na prawą burtę (SW południowy zachód), zaś 2 i 4 eskadry na lewą burtę (SE). W takiej sytuacji manewr odwrotu (Gefechtkehrtwendung ${ }^{25}$ ) nie pozwoliłby Niemcom tak skutecznie uchylić się od walki. Brytyjczycy mogliby liczyć, iż jeśli Hochseeflotte wciąż próbowałaby odwrotu, powolna 2 Eskadra zostałaby z tyłu i byłaby skazana na zniszczenie. Scenariusz, który może wydawać się tak atrakcyjny, był wysoce nieprawdopodobny $\mathrm{z}$ dwóch podstawowych powodów. Po pierwsze, manewr taki wiązałby się z wielkim ryzykiem. Brak koordynacji pomiędzy podzielonymi zespołami Grand Fleet mógłby pozbawić Brytyjczyków atutu przewagi liczebnej, ze wszystkimi konsekwencjami takiej sytuacji.

Drugi zaś powód to obowiązujący w brytyjskiej marynarce wojennej system dowodzenia. W teorii w Royal Navy promowano w tamtym czasie samodzielne działania oficerów flagowych, podobnie zresztą w Kaiserliche Marine. Jednakże praktyka w obu marynarkach wojennych miała $\mathrm{z}$ tym niewiele wspólnego. Wytyczne Jellicoe do bitwy oraz jego Grand Fleet Battle Orders znacząco utrudniły samodzielne działania jego podkomendnym ${ }^{26}$. Preferował on scentralizowany styl dowodzenia. Brytyjscy oficerowie nie byli zachęcani do samodzielnego działania, mieli raczej realizować rozkazy bezpośredniego przełożonego. Własna inicjatywa w praktyce nie była mile widziana - dowódca okrętu nie podejmował działania bez rozkazu dowódcy dywizjonu, ten zaś podążał za rozkazami dowódcy eskadry, który wykonywał polecenia dowódcy floty ${ }^{27}$. Oczywiście im wyższe stanowisko, tym większa była możliwość wykazania własnej inicjatywy. Jednakże mający wpojone posłuszeństwo i dyscyplinę brytyjscy oficerowie rzadko odważali się nią wykazać, co potwierdziło się w czasie bitwy jutlandzkiej. Sturdee mógł snuć wizje tego, co by się wydarzyło, gdyby podjął inną decyzję, ale w czasie walki nie wykazał się własną inicjatywą. Krytyczne podejście

\footnotetext{
24 J. Brookes, The Battle of Jutland, Cambridge 2016, s. 101.
}

25 Gefechtkehrtwendung (pol. zwrot bojowy) - specjalny manewr ćwiczony przez niemiecką flotę, mający umożliwić jej wycofanie się z trudnej sytuacji taktycznej. Polegał on na zwrocie wszystkich okrętów w linii równocześnie o 180 stopni - okręt prowadzący stawał się ostatnim, zaś zamykający szyk zostawał prowadzącym. W ten sposób linia bojowa mogła zawrócić niejako „w miejscu”; zob. C. London, Jutland..., s. 21.

26 J. Brooks, The Battle..., s. 129; Grand Fleet Battle Orders 1915, 1916, Jellicoe Papers, t. XXIII, British Library, s. 13, http://www.bl.uk/manuscripts/FullDisplay.aspx?ref=Add_ MS_49011 (dostęp 17 VII 2019).

27 G. Bennett, Jutlandia..., s. 216. 
brytyjskiego głównodowodzącego do decentralizacji dowodzenia pogłębiała jego opinia o wiceadmirałach stojących na czele eskadr pancerników Grand Fleet. Miał on wprawdzie zaufanie do wadm. Burneya (1 Eskadra Pancerników) oraz wiceadmirała Martyna Jerrama (2 Eskadra Pancerników), jego wieloletnich podkomendnych, ale nie należeli oni do ludzi wykazujących się zbyt dużą inicjatywą. Natomiast wspomniany wadm. Sturdee nie cieszył się największym poważaniem głównodowodzącego ${ }^{28}$. Sytuacja taka w sposób oczywisty rzutowała na możliwości zastosowania bardziej elastycznej taktyki. Admirałowie dowodzący eskadrami, nieprzyzwyczajeni do samodzielnego działania, postawieni nagle w obliczu nowych dla nich wymagań mogliby im nie sprostać.

Kolejny element, rzutujący na możliwości stosowania bardziej wyrafinowanej taktyki, to niedoskonałość będących do dyspozycji środków łączności. Pomimo dokonującego się szybkiego postępu technicznego środki łączności, jakimi dysponowano w tamtym czasie, pozostawiały wiele do życzenia. Możliwości artylerii oraz systemów kontroli ognia w okresie I wojny światowej zdecydowanie wyprzedziły rozwój i praktykę użycia środków łączności. Do komunikowania pomiędzy okrętami oraz zespołami wykorzystywano przede wszystkim flagi i lampy sygnałowe. Taka komunikacja była oczywiście możliwa jedynie w zasięgu obserwacji wzrokowej. Przy warunkach pogodowych obniżających widzialność sytuacja stawała się jeszcze trudniejsza. Nieco większy zasięg dawały sygnały świetlne, ale również ograniczały się do zasięgu wzroku (w najlepszych warunkach sięgały do horyzontu). Przed wojną jako środek łączności rozpowszechnił się radiotelegraf. Umożliwiał on łączność między zespołami flot przy dużych odległościach lub między okrętami przy słabej widzialności. Jednakże było to urządzenie wciąż względnie nowe i zawodne. Dlatego też brytyjskie instrukcje sygnałowe z 1906 r. określały flagi sygnałowe jako główny środek łączności na odległościach nieprzekraczających 5 mil. Jeżeli sygnały były trudne do odróżnienia, należało je powtórzyć innymi środkami. Niemniej według Grand Fleet Signal Orders admirał mógł wydawać rozkazy do akcji oraz manewrów za pomocą radiotelegrafu oraz środków wizualnych (flagi, sygnały świetlne) ${ }^{29}$. Według Andrew Gordona radiotelegraf w tamtym czasie nie nadawał się do wydawania rozkazów flocie podczas akcji. Łączność bezprzewodowa miała być na to zbyt wolna. Wiadomości nadawano alfabetem Morse’a, w związku z czym na ich odczytanie potrzeba było czasu. Dlatego też Brytyjczycy mieli nie stosować radiotelegrafu do rozkazów: przy

\footnotetext{
28 J. Brookes, The Battle..., s. 111-112.

29 Ibidem, s. 49-57; Grand Fleet Battle Orders 1915, 1916, „Jellicoe Papers”, t. XXIII, British Library, s. 17-18, http://www.bl.uk/manuscripts/FullDisplay.aspx?ref=Add_MS_49011 (dostęp 17 VII 2019).
} 
wykonywaniu jednoczesnych manewrów przez kilka okrętów (całą flotę), nagłych manewrach, które należało wykonać zaraz po otrzymaniu sygnału oraz szybkich sekwencji manewrów ${ }^{30}$. W tej kwestii istnieją wśród badaczy różnice zdań i np. John Brookes polemizuje z takim stanowiskiem. Za przykład podaje komentarz Jellicoe, iż w 1916 r. był on w stanie bez większych problemów używać radiotelegrafu do manewrowania całą flotą. Miało się to według niego odbywać szybko i sprawnie (komentarz pochodzi z wydanej po wojnie pracy Jellicoe The Grand Fleet 1914-1916) $)^{31}$. Natomiast bardziej skomplikowane sygnały (zwykle o mniejszym priorytecie) potrzebowały więcej czasu na przesłanie drogą radiową i w ich wypadku komunikacja środkami wizualnymi była sprawniejsza ${ }^{32}$.

Niemcy również opierali swoją łączność na flagach sygnałowych, chociaż użycie radiotelegrafu stało się w Kaiserliche Marine bardziej powszechne niż w Royal Navy. Niemieckie sygnały specjalne używane w czasie akcji miały być nadawane zawsze przy pomocy flag sygnałowych oraz radiotelegrafu jednocześnie. Natomiast sygnałem do ich wykonania było zawsze ściągnięcie flag sygnałowych. Każdy okręt po wykonaniu manewru przesyłał sygnał na następny okręt w szyku ${ }^{33}$.

To wszystko dodatkowo zwiększało ryzyko, jakie niósł ze sobą manewr podziału floty. Brytyjscy admirałowie byli w większości niechętni podejmowaniu skomplikowanych, ryzykownych manewrów. Zdawali sobie sprawę, iż przy ówczesnych środkach łączności może się to skończyć tragicznie. Mieli ku temu praktyczne przykłady. Jednym z najbardziej spektakularnych, wciąż wywierających wpływ na wyobraźnię oficerów Royal Navy, była kolizja pancerników HMS Camperdown i HMS Victoria podczas manewrów w 1893 r., zakończona zatonięciem drugiego z nich ${ }^{34}$. Jellicoe należał do ocalałych z Victorii, co zapewne wywarło na niego znaczący wpływ. Niewykluczone, że wspomnienia o tej tragedii w pewnym stopniu przyczyniły się do ukształtowania jego stylu dowodzenia.

Rozmiar floty, którą przyszło dowodzić Jellicoe również był czynnikiem, którego nie można lekceważyć. Grand Fleet była formacją znacznie większą niż jakakolwiek pojedyncza brytyjska flota jeszcze w poprzedniej dekadzie.

\footnotetext{
30 A. Gordon, The rules of the game, s. 354-355.

31 J. Jellicoe, The Grand Fleet 1914-1916. The creation, development and work, New York 1919, s. 59.

32 J. Brooks, The Battle..., s. 53.

33 Ibidem, s. 61-63.

34 Na HMS Victoria zginął dowódca Floty Morza Śródziemnego wiceadmirał George Tryon. Był autorem uproszczonego systemu sygnałów (nazywanego TA), mającego w założeniu ułatwić wykonywanie skomplikowanych manewrów w warunkach bojowych. Po jego śmierci system ten został zarzucony; zob. A. Gordon, The rules of the game..., s. 307-312.
} 
Co prawda liczba okrętów liniowych służących w Royal Navy w czasach przed Dreadnoughtem bywała większa niż podczas I wojny światowej, niemniej w czasie pokoju były one podzielone na kilka flot, zdecydowanie mniejszych niż Grand Fleet, która grupowała właściwie wszystkie nowoczesne brytyjskie okręty liniowe. Linia bojowa Grand Fleet (24 pancerniki w trzech eskadrach) rozwinięta do akcji rozciągała się na 6 mil morskich $^{35}$. Daje to pojęcie o skali wyzwania, jakim było sprawne prowadzenie tej formacji.

Konkludując, adm. Jellicoe podjął decyzję, którą uznał za najkorzystniejszą wobec posiadanych przez siebie w tamtym czasie informacji. Rozwinął Grand Fleet na lewą burtę (SE). Dzięki temu flota miała więcej czasu na uformowanie szyku bojowego. Jellicoe liczył, iż uda mu się wprowadzić Grand Fleet na kurs prostopadły do Hochseeflotte ścigającej krążowniki liniowe Beatty'ego. Idąc kursem południowo-wschodnim, brytyjska flota miała szansę odciąć Niemcom drogę odwrotu do ujścia rzeki Jade. Jellicoe liczył, iż uda mu się w ten sposób zmusić przeciwnika do podjęcia walki. Ponadto głównodowodzący Grand Fleet spostrzegł, że dzięki temu manewrowi ma szansę postawić Grand Fleet w możliwie najkorzystniejszej sytuacji wobec przeciwnika, jaką tylko można było sobie wyobrazić: poprzez postawienie kreski nad „T”36. Ten cel udało mu się osiągnąć. Dodatkowym czynnikiem przewagi były korzystniejsze w tym momencie dla Brytyjczyków warunki oświetleniowe ${ }^{37}$. Kończąc ten wątek, warto przytoczyć komentarz admirała Andrew Cunninghama, powszechnie szanowanego dowódcy brytyjskiej Floty Morza Śródziemnego oraz Pierwszego Lorda Morskiego z czasów II wojny światowej, który oświadczył, iż na miejscu Jellicoe postąpiłby dokładnie tak samo ${ }^{38}$.

Znalazłszy się w wielkim niebezpieczeństwie, wadm. Scheer był zmuszony wykonać specjalny, starannie wcześniej w marynarce niemieckiej przećwiczony, zwrot bojowy (Gefechtkehrtwendung). Jellicoe nie mógł temu przeciwdziałać, gdyż próba pościgu nie była możliwa bez łamania szyku. Miał inny plan. Postanowił odciąć Niemców od baz, obracając decyzję

\footnotetext{
35 J. Brooks, The Battle..., s. 272.

36 Stawianiem kreski nad „T” nazywa się klasyczny manewr z epoki, gdy na morzu dominował szyk liniowy. Manewr polegał na poprowadzeniu linii bojowej, tak aby znalazła się na drodze szyku liniowego przeciwnika mniej więcej pod kątem prostym (patrząc z góry, obie linie tworzyły wtedy kształt podobny do litery „T”, od czego wzięła się nazwa manewru). W tej sytuacji szyk tworzący kreskę nad „T” miał dużą przewagę, gdyż wszystkie jego okręty mogły prowadzić ogień do przeciwnika pełnymi salwami burtowymi. Natomiast przeciwnik mógł odpowiadać jedynie z czołowych armat prowadzących okrętów.
}

37 Kluczowe było położenie względem Słońca - by oświetlało ono cel, a nie oślepiało artylerzystów; zob. C. London, Jutland 1916 Clash of the Dreadnoughts, Botley - Oxford 2000, s. 56.

38 A. Gordon, The rules of the game..., s. 441. 
Scheera o odwrocie przeciwko niemu. Zgadzało się to z założeniami taktycznymi do starcia flot wypracowanymi przez Jellicoe. Według nich reakcją na odwrót niemieckiej floty miał być nie pościg, lecz zajęcie lepszej pozycji i próba zmuszenia przeciwnika do ponownej konfrontacji ${ }^{39}$. Istotnie, kiedy kolejna decyzja Scheera zawróciła Hochseeflotte z powrotem w kierunku Brytyjczyków, po raz drugi tego dnia Grand Fleet znalazła się w wyśmienitej pozycji, stawiając kreskę nad „T” przeciwnikowi ${ }^{40}$. Niemiecki głównodowodzący ratował swoją flotę kolejnym Gefechtkehrtwendung oraz desperacką szarżą krążowników liniowych wspartą atakiem niszczycieli.

W obliczu ataku torpedowego przeciwnika Jellicoe podjął kolejną decyzję, która do dziś budzi kontrowersje i za którą spotkała go później dotkliwa krytyka oficerów Royal Navy. Admirał rozkazał wszystkim okrętom liniowym, w celu uniknięcia torped, wykonać zwrot na lewą burtę, czyli w przeciwną stronę do atakujących Niemców. Brytyjskie okręty zostały więc zmuszone do przerwania akcji i przez krótki czas poruszały się w przeciwną do Niemców stronę. Zanim Grand Fleet zdołała powrócić na poprzedni kurs i uformować na powrót linię bojową, Hochseeflotte zerwała kontakt i wyszła z pola widzenia. Dodatkowo znów dały o sobie znać kłopoty z komunikacją, gdyż Jellicoe dopiero po pewnym czasie zorientował się, że flota straciła kontakt z Niemcami ${ }^{41}$. Ponieważ była już dość późna godzina i nieuchronnie zbliżał się zachód słońca, brytyjski głównodowodzący nie zdecydował się na pościg. Jellicoe chciał uniknąć nocnej bitwy, ponieważ Niemcy byli do niej dużo lepiej przygotowani niż Brytyjczycy ${ }^{42}$. Zamiast tego postanowił kontynuować plan odcięcia Niemców od ich baz, mając nadzieję, że po świcie 1 czerwca zmusi Scheera do rozstrzygającego starcia.

Rozkaz manewru przeciwtorpedowego jest prawdopodobnie największym zarzutem stawianym adm. Jellicoe przez jego krytyków. O ile sposób rozwinięcia floty doprowadził do uzyskania przez Grand Fleet korzystnej pozycji, to już manewr uchylania się od torped, jak argumentowali przeciwnicy admirała, doprowadził do zmarnowania okazji zadania Hochseeflotte dużych strat. Nikt raczej nie kwestionował przy tym konieczności szybkiej reakcji na atak torpedowy i wykonania manewru unikowego. Niektórzy

\footnotetext{
39 J. Brooks, The Battle..., s. 101.

40 Z. Flisowski, Bitwa..., s. 72.

41 A. Gordon, The rules of the game..., s. 488-489.

42 Niemcy posiadali więcej silniejszych reflektorów szperaczy, a ich okręty miały na wyposażeniu pociski oświetlające, których Brytyjczycy w ogóle nie używali. Załogi niemieckie były intensywniej szkolone do akcji nocnej od brytyjskich. Również niemiecki system świetlnych sygnałów rozpoznawczych stał na wyższym poziomie. Brytyjczycy stosowali sygnały nadawane alfabetem Morse’a, białym światłem. Natomiast Niemcy mieli specjalnie opracowany system kolorowych świateł; zob. ibidem, s. 165.
} 
komentatorzy bitwy sugerowali natomiast, że lepszym rozwiązaniem byłby unik w kierunku torped ${ }^{43}$. Wtedy Grand Fleet zbliżałaby się do Hochseeflotte zamiast się oddalić, a co za tym idzie mogła zachować kontakt bojowy i nie dopuścić do ucieczki przeciwnika ${ }^{44}$. Jellicoe bronił się, twierdząc iż zdecydował się na unik „na zewnątrz”, ponieważ uznał to za rozwiązanie pewniejsze i bezpieczniejsze. Trudno odmówić mu racji, analizując różne wcześniejsze i późniejsze przypadki oraz teorię. Obranie kursu takiego samego jak torpeda zmniejsza relatywną prędkość, z jaką zbliża się ona do okrętu. Daje to załodze więcej czasu na wykonanie pełnego manewru. Pojawia się szansa, iż torpedom może zabraknąć paliwa, jako że dystans, który muszą pokonać, zwiększa się. Wreszcie wejście torpedy w ślad torowy okrętu liniowego idącego $\mathrm{z}$ pełną prędkością i zaburzenia wody powodowane przez śruby mogą doprowadzić do jej zejścia z kursu. Najprawdopodobniej miało to miejsce w przypadku pancernika HMS Neptune, którego załoga zaobserwowała torpedę podążającą bezpośrednio za okrętem, ale nie doszło do eksplozji ${ }^{45}$. Jellicoe wybrał więc po raz kolejny rozwiązanie mające na celu minimalizację własnych strat. Jego krytycy natomiast deklarowali gotowość akceptacji ryzyka trafienia kilku pancerników torpedami i ich poważnego uszkodzenia (potencjalnie konieczności wyjścia z linii) w zamian za zadanie ciężkich strat Niemcom. Tutaj także wyraźnie widać zderzenie ducha Jellicoe z duchem Nelsona. Trzeba jednak zaznaczyć, że głównodowodzący Grand Fleet obawiał się torped i miał ku temu podstawy. Wiedział, że ochrona przeciwtorpedowa na brytyjskich okrętach liniowych była niewystarczająca ${ }^{46}$. Dlatego też uważal, iż nawet pojedyncze trafienie torpedą może mieć dla jego okrętów poważne konsekwencje. Pod tym względem jego decyzja przyniosła oczekiwane efekty - żadna z torped $\mathrm{z}$ tej salwy nie dosięgła jego okrętów. Trzeba tu także zaznaczyć, że obawy Jellicoe były uzasadnione w świetle wcześniejszych doświadczeń: wrażliwość brytyjskich

\footnotetext{
43 C. Bellairs, The Battle of Jutland..., s. 187-188; W. Schliehauf, Jutland: The Naval..., s. 166; J. Harper, R. Bacon, The Jutland Scandal..., s. 182.

44 G. Bennett, Jutlandia..., s. 150.

45 R. Massie, Stalowe Fortece, t. 4, Gdańsk 2015, s. 112.
}

46 Niemieckie okręty posiadały bardzo skuteczny system ochrony przeciwtorpedowej. Opierał się on na pancernej grodzi przeciwtorpedowej, chroniącej żywotne części okrętu (siłownie i magazyny amunicji), odsuniętej na ponad cztery metry od burty okrętu. Przestrzeń między grodzią a burtą była w połowie wypełniona węglem, a w połowie pozostawała pusta. Dodatkowo niemieckie okręty były podzielone na większą liczbę przedziałów wodoszczelnych od swoich brytyjskich odpowiedników (każdy kocioł znajdował się w osobnym przedziale, podczas gdy brytyjskie okręty liniowe miały trzy kotłownie). Brytyjskie okręty liniowe, aż do typu Queen Elizabeth, nie posiadały grodzi przeciwtorpedowej z prawdziwego zdarzenia. Dodatkowo kadłuby niemieckich okrętów liniowych były podzielone na więcej przedziałów wodoszczelnych niż kadłuby okrętów brytyjskich, co zapewniało im większą odporność; zob. G. Staff, German Battleships 1914-1918 [2], Botley - Oxford 2009. s. 7. 
drednotów na wybuchy podwodne potwierdzała utrata HMS Audacious w $1914 \mathrm{r}^{47}$

Kolejna decyzja Jellicoe związana była $\mathrm{z}$ domysłami co do przypuszczalnego kursu floty niemieckiej. Istniały trzy szlaki prowadzące do niemieckich baz w Zatoce Helgolandzkiej. Jedna prowadziła na wschód, na Horns Riff ${ }^{48}$ i na południe wzdłuż wybrzeża Danii, druga bezpośrednio na południe, a następnie na wschód wzdłuż wybrzeży Holandii (droga na Ems). Jellicoe sądził, iż Niemcy nie zdecydują się na trasę koło Horns Riff, ze względu na duże ryzyko napotkania Grand Fleet. Teoretycznie Niemcy mogli też skierować się na północ na Kattegat, ale była to najdłuższa trasa i wiązała się z ryzykiem doścignięcia przez szybszą flotę brytyjską. Biorąc to pod uwagę, Jellicoe wykluczył także tę opcję. Dlatego zdecydował się trzymać kurs na południe. Na wszelki wypadek rozkazał stawiaczowi min HMS Abdiel postawić dodatkowe miny na podejściu do Horns Riff. Flota ustawiła się w nocny szyk marszowy (torowy w czterech kolumnach), co było standardową praktyką. Krążowniki szły przed główną flotą na jej skrzydłach, zaś flotylle niszczycieli tworzyły ariergardę ${ }^{49}$. Plan Jellicoe nie powiódł się. Scheer zdołał w ciemnościach przedrzeć się za brytyjską flotą, napotykając jedynie opór niszczycieli i bezpiecznie dotrzeć do Horns Riff o świcie. Informacja o starciach niszczycieli z Hochseeflotte nie dotarła na brytyjskie pancerniki i kontynuowały one marsz tym samym kursem. Dopiero po wschodzie słońca Jellicoe otrzymał wiadomość od admiralicji o ucieczce Niemców. Na pościg było już za późno. Trudno jednak obciążać admirała całkowitą winą za wymknięcie się niemieckiej floty. Przez całą noc nie miał prawie żadnych informacji o pozycji i ruchach Hochseeflotte. Dowódcy niszczycieli nie poinformowali go o tym, że walczą z głównymi siłami wroga, a gdy jeden $\mathrm{z}$ nich wreszcie wysłał meldunek, ten nigdy nie dotarł na Iron Duke’a. Komunikacja znów zawiodła Brytyjczyków ${ }^{50}$. Zawiodły ich też sztywne zasady oraz niechęć do podejmowania inicjatywy, co zostało już wspomniane. Obserwatorzy na kilku drednotach dostrzegli sylwetki niemieckich krążowników liniowych, które wycofywały się oddzielnie. Niektórzy słyszeli też na swoich tyłach odgłosy walki prowadzonej przez

47 HMS Audacious, nowoczesny pancernik typu King George V wprowadzony do służby w 1913 r., zatonął po wejściu na zaledwie jedną minę; zob. J. Gozdawa-Gołębiowski, T. Wywerka Prekurat, Pierwsza wojna..., s. 66; T. Klimczyk, Historia pancernika, Warszawa 1994, s. $126-127$.

48 Płycizna leżąca ok. $15 \mathrm{~km}$ od najdalej na zachód wysuniętego punku na wybrzeżu Danii. Najczęściej w literaturze dotyczącej obu wojen światowych używana jest angielska nazwa Horns Reef. Duńska nazwa to Horns Rev, natomiast w tekście użyta została pisownia niemiecka.

49 G. Bennett, Jutlandia..., s. 159.

50 Ibidem, s. 186. 
niszczyciele. Żaden z dowódców okrętów nie zdecydował się wyjść z linii ani otworzyć ognia. Nie poinformowali o tych wydarzeniach dowódców swoich eskadr lub głównodowodzącego. Jellicoe nie mógł też, niestety, liczyć na wsparcie admiralicji. Chociaż Room 40 odszyfrował wiele sygnałów Hochseeflotte dotyczących jej kursu oraz pozycji, admiralicja przesłała Jellicoe tylko jedną wiadomość o kursie przeciwnika ${ }^{51}$. Ten zaś nie miał zaufania do informacji admiralicji, gdyż wcześniejsze nie zgadzały się z meldunkami jego własnych oficerów. Gdyby admiralicja przesłała Jellicoe więcej niż jedną wiadomość, to możliwe, że przesłane informacje zostałyby przezeń uznane za wiarygodne, chociaż trudno spekulować, czy wystarczyłyby do podjęcia ryzyka walki nocnej.

Po raz kolejny głównodowodzący Grand Fleet obrał plan działania, który wydawał się najlepszy w obliczu posiadanych przez niego informacji ${ }^{52}$. Tym razem jednak to on został wymanewrowany przez Scheera. Część komentatorów z kręgów Royal Navy krótko po bitwie krytykowała Jellicoe, ponieważ pozwolił uciec Hochseeflotte. Za jego największy błąd, który umożliwił niemieckiej flocie wycofanie się, najczęściej uznawany jest sposób wykonania manewru uchylania się od torped, co zostało wyżej omówione ${ }^{53}$.

Należy zaznaczyć, iż po bitwie głównodowodzący Grand Fleet studiował dogłębnie jej przebieg, skupiając się zwłaszcza na problemie skontrowania niemieckiego odwrotu przez Gefechtkehrtwendung w przypadku ponownego starcia. Korzystał przy tym z pomocy wadm. Sturdee'ego, biorąc pod uwagę także możliwość zastosowania taktyki podzielonej floty. Co ciekawe, Jellicoe uznał, iż taktyka niemiecka była zgodna z brytyjskimi oczekiwaniami formułowanymi przed bitwą. Mimo to jego ostateczny wniosek w kwestii skontrowania niemieckiego manewru był pesymistyczny - na taki manewr przeciwnika: „Nie ma właściwej odpowiedzi” („There is no real counter") $)^{54}$.

Jellicoe można z pewnością zarzucić zbytnią ostrożność, ale żeby właściwie ocenić jego dowodzenie w bitwie jutlandzkiej, należy zadać pytanie: jakie były jego cele przed bitwą oraz jak wyglądała strategiczna sytuacja na Morzu Północnym po bitwie? Jellicoe nie był Nelsonem, ale sytuacja strategiczna wyglądała zupełnie inaczej niż w czasie bitwy pod Trafalgarem. Wtedy Nelson mógł sobie pozwolić na większe ryzyko. Jego flota stanowiła tylko część sił Royal Navy. Natomiast w bitwie jutlandzkiej brała udział praktycznie cała Grand Fleet, w skład której wchodziły prawie wszystkie

\footnotetext{
51 A. Gordon, The rules of the game..., s. 148-152.

52 R. Massie, Stalowe Fortece..., s. 146.

53 J. Brooks, The Battle..., s. 532-533.

54 Battle of Jutland $30^{\text {th }}$ May to $1^{\text {st }}$ June 1916. Official Despaches with Appendices, London 1920, s. 3.
} 
nowoczesne, brytyjskie okręty liniowe ${ }^{55}$. Zniszczenie Grand Fleet lub zbyt poważne straty, które doprowadziłyby do utraty przewagi nad Hochseeflotte, miałyby dla Wielkiej Brytanii katastrofalne skutki ${ }^{56}$. Wprawdzie nie istniało zagrożenie inwazją, ale nie była ona konieczna, aby wyłączyć Zjednoczone Królestwo z wojny. Panowanie nad wodami Kanału La Manche przez Niemców oznaczałoby odcięcie armii brytyjskiej walczącej we Francji od zaplecza. Poważniejszą konsekwencją uwolnienia Hochseeflotte byłaby możliwość ustanowienia blokady Wysp Brytyjskich bez konieczności uciekania się do nieograniczonej wojny podwodnej. Historycy często przytaczają słowa Winstona Churchilla, Pierwszego Lorda Admiralicji w pierwszych dwóch latach wojny, który stwierdził: „Jellicoe był jedynym człowiekiem po obu stronach, który mógł przegrać wojnę w ciągu jednego popołudnia"57.

Jellicoe zdawał sobie sprawę z odpowiedzialności, jaka spoczywała na jego barkach i dlatego wolał zachowywać maksymalną ostrożność i raczej minimalizować własne straty, niż maksymalizować straty przeciwnika ${ }^{58}$. Brytyjczycy mieli sporą przewagę nad Kaiserliche Marine, która oddała im panowanie na Morzu Północnym właściwie bez walki. Prowadzili aktywną blokadę Niemiec, zaś Hochseeflotte przez większość czasu pozostawała w swoich bazach, chroniąc się za polami minowymi Zatoki Helgolandzkiej. Po bitwie ta sytuacja pozostała bez zmian. Jellicoe walczył o to, aby zachować status quo, a nie żeby je zmienić. To Niemcy potrzebowali zadać przeciwnikowi jak największe straty. Dla Grand Fleet wystarczyło, aby nie poniosła zbyt dużych strat. Tym kierował się jej głównodowodzący i to udało mu się osiągnąć. Oczywiście zredukowanie siły Hochseeflotte byłoby korzystne dla Brytyjczyków, ale nie zmieniłoby zasadniczo sytuacji strategicznej ${ }^{59}$. Zniszczenie niemieckiej marynarki wojennej nie przybliżyłoby Ententy do zwycięstwa w wojnie. Nie istniał żaden inny przeciwnik, który mógłby

55 Z brytyjskich drednotów udziału w bitwie nie wzięły jedynie trzy: HMS Dreadnought, Emperor of India i HMS Queen Elizabeth; zaś z krążowników liniowych jedynie HMS Australia. Dodatkowo w stoczniach trwała budowa trzech nowych drednotów i dwóch krążowników liniowych.

56 Sam Jellicoe opisywał w ten sposób swoją sytuację w 1916 r. - i to jak różna była ona w porównaniu z Trafalgarem; zob. J. Jellicoe, The Grand Fleet..., s. 302.

57 C. London, Jutland..., s. 7.

58 J. Brookes, The Battle..., s. 109.

59 Niektórzy, np. komandor US Navy Charles Gill, trzy lata po wojnie sugerowali, iż zdecydowane brytyjskie zwycięstwo miałoby poważne konsekwencje dla wojny. Współcześnie Beckett w swojej historii I wojny światowej pisze, iż w takiej sytuacji Brytyjczycy zyskaliby dostęp do Bałtyku. Niemniej zaraz uznaje, iż nie uchroniłoby to caratu przed upadkiem, co tym bardziej podważa wpływ takiej sytuacji na przebieg wojny; zob. C. Gill, What happened at Jutland. The tactics of battle, New York 1921, s. 26; I. F. W. Beckett, The Great War 1914-1918, London 2007, s. 252. 
zagrażać Grand Fleet. Nie było również żadnego miejsca, w którym można byłoby ją zaangażować, aby wpłynąć na ogólną sytuację wojenną. Mała flota austro-węgierska nie stanowiła poważnego zagrożenia i była uwięziona na Morzu Adriatyckim. Floty francuska i włoska w zupełności wystarczyły, aby trzymać ją w szachu. Plany ataku z morza na Bosfor i Dardanele już dawno porzucono po porażce operacji na Gallipoli ${ }^{60}$. Z punktu widzenia Jellicoe nadmierne ryzyko nie miało żadnego sensu. Mając w świadomości ogólną sytuację wojenną, postępowanie admirała należy ocenić jako przejaw rozsądku, nie zaś niezdecydowania czy też kunktatorstwa. Duży wpływ na przebieg bitwy miały czynniki bezpośrednio niezależne od samego Jellicoe techniczne ograniczenia rzutujące na możliwości komunikowania się oraz konieczność przewidywania posunięć przeciwnika właściwie na oślep. Biorąc to wszystko pod uwagę, można stwierdzić, że adm. Jellicoe nie popełnił znaczących błędów i osiągnął cel strategiczny: zmusił przeciwnika do odwrotu, nie ponosząc zbyt dużych strat ${ }^{61}$.

Analizując bitwę jutlandzką, warto zwrócić uwagę na zbieżność postępowania Jellicoe $\mathrm{z}$ teoriami sir Juliana Corbetta. Był on brytyjskim analitykiem oraz historykiem zajmującym się wojną na morzu. W swoich pracach wchodził w polemikę z teoriami amerykańskiego admirała Alfreda Mahana, które zyskały dużą popularność na świecie przed I wojną światową. Mahan dowodził, iż do panowania na morzu konieczne jest fizyczne wyeliminowanie wrogiej floty w wyniku decydującej bitwy. Natomiast Corbett odrzucał to założenie. Twierdził, iż do zwycięstwa w wojnie wystarczy zapewnienie sobie przewagi na morzu i utrzymanie jej. Preferował strategiczną defensywę. Doradzał stosowanie blokady morskiej i odcięcie przeciwnika od handlu, niejako zmuszając go do podjęcia ofensywnych akcji w niesprzyjających dla siebie warunkach. Corbett zalecał też minimalizowanie strat własnych i stawiał priorytet zachowaniu zdolności bojowych własnych, kosztownych okrętów, nawet za cenę zadania mniejszych strat przeciwnikowi ${ }^{62}$. Brytyjski głównodowodzący działał w dużej mierze zgodnie z zaleceniami Corbetta, nie podejmując niepotrzebnego ryzyka.

W przeciwieństwie do Jellicoe wadm. David Beatty nie spotkał się z tak poważną krytyką zaraz po bitwie. Ponieważ był tylko podkomendnym Jellicoe, wydawać się mogło, że nie może ponosić odpowiedzialności za ostateczny wynik starcia. Jednakże wraz z upływem czasu wokół jego poczynań zaczęły narastać wątpliwości. Może się to wydawać paradoksalne, gdyż zarzuty stawiane Beatty'emu miały dokładnie odwrotny charakter do tego, o co oskarżano Jellicoe. Dowódca Floty Krążowników Liniowych znany

\footnotetext{
60 J. Gozdawa-Gołębiowski, T. Wywerka Prekurat, Pierwsza wojna..., s. 233.

61 J. Brooks, The Battle..., s. 532-533.

62 J. Corbett, Some principles of Maritime Strategy, London 1911, s. 174-214, 279-317.
} 
był ze swojego agresywnego stylu dowodzenia, czasem graniczącego wręcz $\mathrm{z}$ brawurą.

Gdy Beatty otrzymał raport o kontakcie z nieprzyjacielem, którym wkrótce okazała się niemiecka 1 Grupa Rozpoznawcza, rozkazał swojemu zespołowi iść jak najszybciej w jej kierunku. Tu jednak popełnił pierwszy poważny błąd. Rozkaz nie dotarł do kadm. Evana-Thomasa dowódcy 5 Eskadry Pancerników. Beatty nie upewnił się, czy jego rozkazy dotarły do wszystkich podległych mu jednostek. Pancerniki 5 Eskadry zostały w tyle i musiały gonić Zespół Krążowników Liniowych, nie uczestnicząc w pierwszym etapie starcia. Pod ich nieobecność Beatty dysponował przewagą liczebną w postaci tylko jednego krążownika liniowego - raczej iluzoryczną w starciu z przeciwnikiem dysponującym skuteczniejszą artylerią i silniejszym opancerzeniem jednostek. Admirał skoncentrował się całkowicie na pościgu, próbując zniszczyć okręty swojego niemieckiego odpowiednika kadm. Hippera. Trzeba zaznaczyć, że ani Jellicoe, ani Beatty nie wiedzieli, iż cała Hochseeflotte wyszła tego dnia w morze ${ }^{63}$. Beatty'emu mogło wydawać się, że dojdzie do powtórki bitwy na Dogger Bank ${ }^{64}$. Tymczasem bitwa przybrała niekorzystny obrót dla Brytyjczyków, czego kulminacją było zniszczenie HMS Indefatigable. Problemy z łącznością miały więc pierwsze poważne konsekwencje. Gdyby cztery pancerniki 5 Eskadry od początku brały udział $\mathrm{w}$ walce, jej przebieg mógłby być zupełnie inny, zwłaszcza iż strzelały one dużo lepiej niż krążowniki liniowe Beatty’ego. Z drugiej strony już po ich włączeniu się do bitwy Brytyjczycy utracili HMS Queen Mary. Pomimo utraty dwóch ze swoich sześciu krążowników liniowych Beatty kontynuował pościg, co wiele mówi na temat jego charakteru. Mając ze sobą cztery drednoty, dysponował wciąż dużą przewagą nad Niemcami. Nie zdawał sobie jednak sprawy, iż jest prowadzony w pułapkę.

Gdy siły rozpoznawcze zameldowały mu o pojawieniu się głównych sił Hochseeflotte, natychmiast zarządził zwrot o 180 stopni i pospieszny odwrót. Była to decyzja jak najbardziej słuszna, gdyż jego zespół nie miał szans w starciu z całą Hochseeflotte. Jednakże Beatty nie próbował po prostu ratować swojego zespołu, tylko wykonywał zadanie powierzone mu przez Jellicoe. Miał naprowadzić ścigającą go flotę niemiecką na główne siły Grand Fleet. W momencie odwrotu popełnił jednak kolejny błąd, dokładnie taki sam jak poprzednio. Okazało się, że rozkaz o odwrocie nie został w porę

63 C. London, Jutland..., s. 38.

6424 I 1915 r. miała miejsce bitwa na Ławicy Dogger (Dogger Bank). Było to starcie między zespołem brytyjskich i niemieckich krążowników liniowych (Flota Krążowników Liniowych: pięć krążowników liniowych; I Grupa Rozpoznawcza - trzy krążowniki liniowe i krążownik pancerny SMS Blücher). W obliczu przewagi przeciwnika Niemcy uciekli, w wymianie ognia zatopiony został Blücher. Brytyjczycy przerwali pościg w wyniku nieprecyzyjnych sygnałów oraz błędnej interpretacji rozkazów Beatty’ego po uszkodzeniu flagowego Liona. 
zrozumiany przez kadm. Evana-Thomasa, przez co 5 Eskadra jeszcze przez jakiś czas zbliżała się do przeciwnika. Zwrot wykonała za późno i już pod ostrzałem nieprzyjaciela. Okręty Evana-Thomasa miały dużo szczęścia, gdyż pomimo wielu otrzymanych trafień żadne z nich nie okazało się krytyczne i wszystkie cztery przetrwały bitwę. W sytuacji, w jakiej się znalazły, zmniejszenie prędkości któregoś z okrętów wystawiłoby go na ogień całej floty niemieckiej, co oznaczało jego niechybną zgubę ${ }^{65}$.

Prowadząc Hochseeflotte w kierunku głównych sił Grand Fleet, Beatty przez długi czas nie informował swojego przełożonego o pozycji wrogiej floty. Tymczasem Jellicoe potrzebował jak najdokładniejszych informacji o ruchach przeciwnika, aby skutecznie rozwinąć swoją flotę i zastawić pułapkę. Jako że w końcu Beatty przekazał swojemu zwierzchnikowi pożądane przez niego dane, ten zaś rozwinął swe siły bez komplikacji, można przyjąć, że swoje główne zadanie naprowadzenia Hochseeflotte na brytyjskie siły główne Beatty wykonał należycie. W dalszej części bitwy Beatty prowadził swój zespół już bez brawury. Przed zachodem słońca doszło do jeszcze jednego starcia z 1 Grupą Rozpoznawczą oraz niemiecką 2 Eskadrą Pancerników. Gdy te ostatnie zerwały kontakt bojowy, Beatty zrezygnował z pościgu, podporządkowując się rozkazom adm. Jellicoe - który zamierzał nawiązać dalszą walkę z Hochseeflotte dopiero po świcie ${ }^{66}$. Do tego jednak, jak wiadomo, już nie doszło.

Z perspektywy taktycznej dowodzenie Beatty'ego Flotą Krążowników Liniowych podczas bitwy jutlandzkiej można ocenić jako poprawne, chociaż nie ustrzegł się kilku poważnych błędów. Przede wszystkim dwukrotnie pozostawił 5 Eskadrę Pancerników z tyłu, za pierwszym razem redukując swoją przewagę, za drugim narażając 5 Eskadrę na zniszczenie. Pierwsza sytuacja miała niewątpliwie związek z jego agresywnym stylem dowodzenia. Chciał zapewne za wszelką cenę nie dopuścić do ucieczki Hippera, tak jak to się stało na Dogger Bank. Nie usprawiedliwia to jednak nierozsądnego dysponowania otrzymanymi siłami. Niemniej zarzuty można by wysunąć również pod względem kadm. Evana-Thomasa, który pomimo iż widział manewry krążowników liniowych, nie wykazał własnej inicjatywy ani nie próbował sam potwierdzić rozkazów swojego bezpośredniego przełożonego. Swoje główne zadanie Beatty wykonał wzorowo, pozwalając Grand Fleet zająć korzystną pozycję do starcia flot. Natomiast kilkukrotnie nie przesłał informacji o pozycji wrogiej floty do Jellicoe, wtedy gdy głównodowodzący szczególnie tego potrzebował. Podczas odwrotu Hochseeflotte nie był w stanie utrzymać kontaktu z przeciwnikiem. Najważniejsze zarzuty obciążające Beatty'ego dotyczą przygotowań podległych mu jednostek do walki. W tym

66 J. Corbett, Naval Operations..., s. 291. 
kontekście wskazuje się na brak treningu jego załóg artyleryjskich w realnych warunkach oraz niefortunne próby uzyskania wyższej szybkostrzelności, poprzez lekceważenie procedur bezpieczeństwa, co najprawdopodobniej było jedną z głównych przyczyn eksplozji na krążownikach liniowych ${ }^{67}$. Znamienne jest, iż wśród współczesnych historyków zajmujących się bitwą jutlandzką to właśnie Beatty, a nie Jellicoe, jest obiektem najcięższej krytyki, jak to miało miejsce w pierwszych latach po Wielkiej Wojnie ${ }^{68}$.

Przy analizie brytyjskiej taktyki w bitwie jutlandzkiej należy skomentować wykorzystanie sił rozpoznawczych. Działania dowódców poszczególnych eskadr krążowników były podporządkowane rozkazom ich bezpośrednich przełożonych i nie wykazywali się oni inicjatywą. Pozytywnie można ocenić postawę komodora Williama Goodenougha dowódcy 2 Eskadry Krążowników Lekkich (2 Light Cruiser Squadron), która prowadziła zwiad na czele Zespołu Krążowników Liniowych. To jego okręty wykryły zbliżające się główne siły Hochseeflotte w końcowej fazie „wyścigu na południe”. Jego natychmiastowy meldunek pozwolił Beatty’emu wykonać manewr odwrotu odpowiednio wcześnie ${ }^{69}$. Umożliwił też Jellicoe wcześniejsze zorientowanie się w sytuacji i przygotowanie odpowiedniego planu działania. Sam zaś zdołał ujść spod ostrzału niemieckich pancerników bez strat w okrętach (chociaż istotnym czynnikiem, oprócz umiejętności komodora, było tu szczęście). Po połączeniu się sił brytyjskich 2 Eskadra zajęła miejsce na tyłach floty liniowej. Udało się jej utrzymać kontakt $\mathrm{z}$ wycofującą się Hochseeflotte po jej pierwszym zwrocie bojowym. Informacje od Goodenougha ułatwiły Jellicoe postawienie kreski nad „T” po raz drugi ${ }^{70}$. Po zachodzie słońca eskadra znalazła się z powrotem na przedzie floty. Udało jej się jednak uzyskać tylko jeden kontakt bojowy z niemieckimi krążownikami, zakończony krótką wymianą ognia. Najpoważniejsza krytyka Goodenougha wiąże się z dłuższym okresem, kiedy nie przesyłał żadnych raportów o ruchach Hochseeflotte, w czasie gdy Jellicoe najbardziej ich potrzebowal, przygotowując się do rozwinięcia floty. Miało to miejsce w trakcie „wyścigu na północ" (Run to the North) ${ }^{71}$. Natomiast dowódcy pozostałych eskadr przez większość czasu trzymali się swojego miejsca w szyku. Doszło do kilku starć pomiędzy siłami rozpoznawczymi obu stron, ale brytyjscy

\footnotetext{
67 Aby osiągnąć większą szybkostrzelność, pozostawiano otwarte drzwi do magazynów kordytu w czasie akcji. Składowano też nadmierną ilość pocisków i ładunków motających na pokładzie manipulacyjnym wewnątrz barbety; zob. M. Stille, British Battlecruisers vs German Battlecruisers 1914-1916, Botley - Oxford 2013, s. 19; A. Gordon, The rules of the game..., s. 542.

68 J. Brooks, The Battle..., s. 541-543.

69

C. London, Jutland..., s. 50.

70

G. Bennett, Jutlandia..., s. 145.

71 A. Gordon, The rules of the game..., s. 421-422.
} 
dowódcy nie informowali swoich przełożonych o kontakcie z przeciwnikiem. Było to sprzeczne z rozkazami Jellicoe dla Grand Fleet, które nakładały na dowódców krążowników obowiązek meldowania o pozycji i ruchach przeciwnika dowódcę floty oraz swojego bezpośredniego przełożonego ${ }^{72}$. Przykładem może być starcie 3 Eskadry Krążowników Lekkich kontradmirała Trevylyana Napiera z 4 Grupą Rozpoznawczą (IV Aufklärungsgruppe) kontradmirała Ludwiga von Reutera około godz. 20:00. Wiceadmirał Beatty ruszył $\mathrm{w}$ ich stronę jedynie dzięki temu, iż z jego okrętów widoczne były błyski wystrzałów i słyszalny huk dział. Dzięki tej reakcji doszło do jego spotkania z niemieckimi krążownikami liniowymi i ich ostatniej wymiany ognia tego dnia ${ }^{73}$. Zwłaszcza w nocy brytyjskie krążowniki nie były $\mathrm{w}$ stanie odnaleźć przeciwnika. Część winy ponosi za taki stan sytuacji adm. Jellicoe, który jako głównodowodzący floty nie zdecydował się wydać poleceń bardziej aktywnego działania dowódcom sił rozpoznawczych. Zamiast tego poprzestał na zachowaniu standardowej, dosyć ścisłej, formacji. Zdecydowanie negatywnie należy natomiast ocenić postępowanie dowódcy 1 Eskadry Krążowników (1 Cruiser Squadron) kontradmirała Roberta Arbuthnota. Wyszedł na kurs, który zbliżał go do wrogiej floty, pomimo słabej widoczności. Koncentrując się na już unieruchomionym SMS Wiesbaden zupełnie zaniedbał wszelkie środki ostrożności, nie biorąc pod uwagę ogólnej sytuacji taktycznej. Wyprowadziło to jego eskadrę pod ogień dużej części Hochseeflotte na małym dystansie, którego jego przestarzałe okręty nie były w stanie wytrzymać. Ta nieusprawiedliwiona niczym brawura kosztowała go własne życie oraz utratę trzech krążowników pancernych oraz całych załóg dwóch z nich ${ }^{74}$.

\section{Niemcy}

Dowodzenie w bitwie jutlandzkiej po stronie niemieckiej nie wzbudza tak dużych kontrowersji jak po stronie brytyjskiej. Decyzje wiceadmirała Scheera nie stały się przedmiotem tak wielkiej krytyki jak w przypadku jego głównego adwersarza. Chociaż w późniejszym czasie pojawiły się głosy krytyczne w stosunku do jego dowodzenia tamtego dnia, to jednak do dziś nie osiągnęły one nawet zbliżonych rozmiarów do tych dotyczących Jellicoe. Dodatkowo wadm. Scheer uchodzi w Niemczech za postać wyróżniającą się pozytywnie w porównaniu ze swoimi - pasywnymi - poprzednikami. Niemniej dokładna analiza przebiegu bitwy jutlandzkiej nie pozostawia wątpliwości, iż popełnił kilka poważnych błędów, znacznie większych niż Jellicoe,

72 Grand Fleet Battle Orders 1915, 1916, Jellicoe Papers, t. XXIII, British Library, s. 52, http://www.bl.uk/manuscripts/FullDisplay.aspx?ref=Add_MS_49011 (dostęp 17 VII 2019).

73 C. London, Jutland..., s. 72.

74 Z. Flisowski, Bitwa..., s. 85. 
które mogły bardzo drogo kosztować jego flotę. Z drugiej strony udało mu się wyprowadzić Hochseeflotte z ciężkiego położenia, w którym postawiły ją jego własne decyzje i bez poważniejszych strat wycofać do bazy.

Założenia operacyjne planu bitwy Scheera były jakby lustrzanym odbiciem założeń brytyjskich. Planował wywabić część Grand Fleet (głównie Zespół Krążowników Liniowych lub potencjalnie jedną eskadrę pancerników) przy użyciu 1 Grupy Rozpoznawczej kadm. Hippera. Miała ona następnie naprowadzić brytyjski zespół na główne siły Hochseeflotte, które mając przewagę, byłyby w stanie go zniszczyć lub zadać mu poważne straty, co zredukowałoby ogólną przewagę brytyjskiej marynarki wojennej nad Niemcami ${ }^{75}$. Trzeba tu zaznaczyć, iż Scheer znajdował się w znacząco mniej komfortowej sytuacji od Brytyjczyków, jeśli chodzi o dane wywiadowcze. Niemieckie jednostki dekryptażu były w stanie odczytywać tylko część brytyjskich depesz, natomiast Room 40 dzięki pozyskaniu niemieckich ksiąg kodowych, co zostało już wspomniane, mógł odczytać każdy przechwycony niemiecki rozkaz. Nawet jeśli przysyłanie kluczowych informacji do dowództwa Grand Fleet nie zawsze funkcjonowało sprawnie, dawało Brytyjczykom dużą przewagę. Wiceadmirał Scheer musiał polegać na bardziej konwencjonalnych metodach pozyskiwania informacji o przeciwniku. Przed wyruszeniem floty niemiecki głównodowodzący wysłał okręty podwodne, aby patrolowały podejścia do głównych baz brytyjskiej floty (szczególnie Scapa Flow i Rosyth) i informowały w przypadku wyjścia przeciwnika w morze. Dwa z wysłanych okrętów podwodnych - patrolujące podejścia do Firth of Forth - zdołały zaobserwować ruchy brytyjskiej floty. U32 namierzył elementy Floty Krążowników Liniowych, natomiast bardziej na północ U66 zauważył 2 Eskadrę Pancerników (idącą z Cromarty). Dodatkowo niemieckie biuro deszyfrujące w Neumünster odczytało przechwycone brytyjskie komunikaty o wyjściu w morze znacznych sił (dwóch dużych okrętów lub dwóch eskadr) ze Scapa Flow. Przechwycony został też raport o prognozie pogody w Firth of Forth, przesłany do niemieckiego dowództwa $\mathrm{z}$ komentarzem, iż takowy pojawia się tylko przy wyjściu w morze floty. Dowództwo Hochseeflotte zignorowało te wiadomości, uznając że ruchy brytyjskiej floty nie mają nic wspólnego z zaplanowaną przez nich operacją ${ }^{76}$. Scheer nie zdawał sobie więc sprawy, iż cała Grand Fleet opuściła bazy i zmierza w stronę Skagerraku. Dlatego też gdy 1 Grupa Rozpoznawcza nawiązała kontakt z Zespołem Krążowników Liniowych, Scheer mógł założyć, iż jest to jedyny duży zespół brytyjski na Morzu Północnym.

76 J. Brooks, The Battle..., s. 162-164. 
Niemcy przystąpili więc do realizacji planu. Gdy Hipper naprowadził siły Beatty'ego na Hochseeflotte, ta ruszyła w pościg za uchodzącymi Brytyjczykami. Można kwestionować decyzję Scheera o długotrwałym pościgu. Brytyjskie krążowniki liniowe były szybsze od niemieckich, zaś pancerniki typu Queen Elizabeth od niemieckich pancerników, w związku z czym teoretycznie Niemcy nie mieli szans dogonić Beatty’ego. Jednakże nawet pojedyncze szczęśliwe trafienie mogło skutkować zmniejszeniem prędkości któregoś z okrętów, dzięki czemu stałby się łatwym łupem dla niemieckiej floty. Scheerowi wydawało się, iż niczym nie ryzykuje, nie zdawał sobie sprawy, iż jest prowadzony w pułapkę. Pierwszy poważny zarzut, jaki można mu postawić, dotyczy właśnie pościgu. Uchodząca Flota Krążowników Liniowych obrała kurs północno-wschodni, aby naprowadzić ścigających na korzystną dla Grand Fleet pozycję. Nikt z niemieckiego dowództwa nie zastanowił się dlaczego Beatty odbija na wschód, zamiast w kierunku swoich baz ${ }^{77}$. Zapewne można było powziąć podejrzenie, iż ma ku temu jakiś ukryty powód. $\mathrm{Z}$ drugiej strony łatwo jest oceniać działania dowódców z perspektywy historycznej, natomiast $\mathrm{w}$ trakcie bitwy sytuacja rzadko przedstawia się jasno.

Scheer zakładał, że powinien otrzymać informację o wyjściu głównych sił Grand Fleet w morze - skoro takiej nie było, kontynuował pogoń. Przy pogarszającej się widoczności Hochseeflotte weszła prosto w pułapkę zastawioną przez Jellicoe i znalazła się w niebezpiecznej sytuacji. Część winy za taki obrót spraw spada na wadm. Scheera jako głównodowodzącego flotą. Mógł podjąć większe środki ostrożności w związku z dziwnym kursem zespołu Beatty’ego. Na jego obronę należy zaznaczyć, że działał w trudnych warunkach (ograniczona widoczność), przy braku informacji o przeciwniku, zaś Jellicoe wykonał swój plan znakomicie. Scheer widział w tej akcji szansę na zadanie strat Brytyjczykom, która mogła się prędko nie powtórzyć. Mając w pamięci pasywność swoich poprzedników, przez którą Niemcy utracili przynajmniej jedną podobną okazję, wolał zaryzykować i wykazać się większą agresją ${ }^{78}$. Tym razem okazało się to błędem. Scheer musiał wykonać Gefechtkehrtwendung, aby uratować flotę. Podjęcie walki w sytuacji, w jakiej znalazła się Hochseeflotte, kosztowałoby Niemców

77 G. Bennet, Jutlandia..., s. 119.

7816 VIII 1914 r. niemieckie krążowniki liniowe zbombardowały miejscowości Scarborough i Whitby. Za Hipperem podążały główne siły Hochseeflotte liczące 14 drednotów. Nieświadomi obecności wrogiej floty liniowej Brytyjczycy wysłali do akcji Flotę Krążowników Liniowych wspartą przez 2 Eskadrę Pancerników w liczbie sześciu drednotów. Głównodowodzący niemieckiej floty admirał von Ingenohl był jednak przekonany, że ma naprzeciwko siebie całą Grand Fleet i rozkazał odwrót. Zmarnował w ten sposób wymarzoną okazję, w której Niemcy mieli przewagę i mogli zadać Brytyjczykom poważne straty, znacznie zmieniając układ sił na swoją korzyść; zob. C. London, Jutland..., s. 23. 
bardzo drogo. Próba wykonania odwrotu w klasyczny sposób tzn. okręt za okrętem byłaby jeszcze gorszym pomysłem. Niemiecki manewr, specjalnie opracowany i ćwiczony właśnie na taką ewentualność, okazał się skuteczny i Hochseeflotte zdołała zerwać kontakt z przeciwnikiem przy zachowaniu szyku bojowego. Przed Scheerem pojawił się jednak nowy problem. Jego flota szła kursem południowo-zachodnim (SW), który oddalał ją od baz w Zatoce Helgolandzkiej. Im dłużej na nim pozostawała, tym większe rysowało się ryzyko, iż Grand Fleet odetnie Niemcom drogę odwrotu. Zdając sobie $\mathrm{z}$ tego sprawę, Scheer musiał podjąć jakieś środki zaradcze. Jednakże decyzja, jaką podjął, należy do jednej z najbardziej kontrowersyjnych w całej bitwie. Wydaje się do dzisiaj niezrozumiała dla większości badaczy bitwy i zupełnie nielogiczna. Scheer rozkazał kolejny zwrot bojowy, wprowadzający flotę z powrotem na kurs północno-wschodni (NE). Na skutek tego powtórzyła się sytuacja, w której niemiecka flota napotkała Grand Fleet w niezwykle niekorzystnej dla siebie sytuacji. Scheer po bitwie próbował tłumaczyć ten manewr próbą wyjścia na tyły brytyjskiej floty i stworzenia nieco odwrotnej wersji postawienia kreski nad ich „T"79. Trudno uznać to za zupełnie wiarygodne tłumaczenie, ale równie trudno znaleźć inne sensowne wytłumaczenie decyzji głównodowodzącego Hochseeflotte ${ }^{80}$. Większość historyków analizujących bitwę nie ma natomiast wątpliwości, iż był to największy błąd Scheera i to być może nie tylko w tej bitwie, ale w całej jego karierze ${ }^{81}$. Trudno się nie zgodzić $\mathrm{z}$ taką opinią. Jedynym efektem niemieckiego manewru było sprezentowanie Brytyjczykom drugiej idealnej okazji do unicestwienia niemieckiej floty, co ostatecznie kosztowało Niemców dodatkowe uszkodzenia i straty w ludziach. W tej sytuacji Scheer nakazał trzeci zwrot bojowy. Żeby przykryć odwrót głównych sił floty, rzucił też do ataku na bliski dystans krążowniki liniowe Hippera. Wspomóc je miał atak niszczycieli, które postawiły zasłonę dymną ${ }^{82}$. Rozkaz praktycznie samobójczego ataku krążowników liniowych pokazuje, w jak dramatycznej sytuacji znaleźli się Niemcy. Szarża niemieckich krążowników liniowych, z których niektóre były już poważnie uszkodzone, groziła utratą wszystkich okrętów tego typu. Można krytykować Scheera za ten rozkaz, ale czasu na decyzję miał niewiele. Znając jej konsekwencje, można uznać, że była właściwa. Wszystkie

\footnotetext{
79 Ibidem, s. 66.
}

80 Po bitwie Scheer przyznał, że tak naprawdę nie wiedział, co robi. Podobnie wyraził się jego szef sztabu, stwierdzając, że gdyby Scheer wykonał podobny ruch podczas manewrów w czasie pokoju, nigdy więcej nie powierzono by mu dowodzenia flotą, zaś wszyscy świadkowie zwątpiliby w jego umiejętności taktyczne; zob. J. Brooks, The Battle..., s. 311-313.

81 Ibidem, s. 519; A. Gordon, The rules of the game..., s. 458.

82 J. Corbett, Naval Operations..., s. 282. 
biorące udział w szarży krążowniki liniowe przetrwały starcie, chociaż za cenę ciężkich uszkodzeń i dodatkowych strat wśród załóg. Gdyby jednak choć jeden z okrętów Hippera miał mniej szczęścia i został utracony, opinie na ten temat mogłyby być zupełnie odmienne. $Z$ drugiej strony niemieckie pancerniki miały pewne problemy $\mathrm{z}$ wykonaniem trzeciego pod rząd Gefechtkehrtwendung i jeśli uwaga Grand Fleet nie skoncentrowałaby się na 1 Grupie Rozpoznawczej, to mogłyby poważnie ucierpieć. Najważniejszy okazał się atak niszczycieli, który zmusił Jellicoe do wykonania manewru unikowego ze wszystkimi konsekwencjami tej decyzji. Scheerowi udało się po raz drugi wyprowadzić flotę z ciężkiej sytuacji z relatywnie niewielkimi stratami, co niewątpliwie trzeba zaliczyć jako jego sukces. Nie można jednak zapominać, iż Hochseeflotte znalazła się w opresji przez wcześniejszy błąd niemieckiego admirała. Niemieckiej flocie wciąż groziło odcięcie drogi powrotnej do baz.

Zapadał zmrok i Scheer postanowił ten fakt wykorzystać. Zamierzał przedrzeć się do baz pod osłoną ciemności. Jak już zostało wspomniane, miał do wyboru trzy drogi. Zdecydował się na trasę koło Horns Riff na wschód, a później na południe wzdłuż wybrzeża. Sądził, że Brytyjczycy nie będą się spodziewać wyboru tej drogi przez Niemców jako najbardziej ryzykownej ${ }^{83}$. Jego konkluzja okazała się słuszna. Następnie bardzo zręcznie poprowadził Hochseeflotte, przechodząc z tyłu szyku Grand Fleet niezauważony przez jej główne siły ${ }^{84}$. Dzięki temu manewrowi Hochseeflotte wyrwała się Brytyjczykom i zdołała szczęśliwie dotrzeć do Zatoki Helgolandzkiej. Za to Scheerowi z pewnością należy się uznanie. Miał też jednak sporo szczęścia. Należy pamiętać, iż jeśli przepływ informacji funkcjonowałby w brytyjskiej flocie prawidłowo, Jellicoe miałby szansę przechwycić Niemców o świcie. Tak się nie stało i wkrótce po powrocie floty cesarz Wilhelm II mógł ogłosić wielkie zwycięstwo.

W historiografii dominują raczej pozytywne oceny Scheera i jego dowodzenia w bitwie jutlandzkiej. Udało mu się podjąć walkę z przeważającymi siłami przeciwnika i zadać mu większe straty, niż poniosła jego własna flota, po czym wycofać się w trudnych warunkach. To wszystko zaś w obliczu przewagi informacyjnej Brytyjczyków. Pochwały Scheera oraz zaoferowanie mu tytułu szlacheckiego przez cesarza świadczą o wysokiej ocenie jego umiejętności i dokonań zaraz po bitwie. Należy jednak pamiętać, iż miały one przede wszystkim charakter propagandowy. Ostatecznie Scheer niewiele więcej mógł zrobić. Zdarzają się badacze, którzy oceniają dowodzenie Scheera jednoznacznie negatywnie. Arthur Marder pisał o nim bardzo krytycznie. Scheer spisał się według niego bardzo źle,

83 C. London, Jutland..., s. 73.

84 Ibidem, s. 83. 
ponieważ przy każdym spotkaniu z głównymi siłami Grand Fleet Jellicoe udawało się go wymanewrować i postawić kreskę nad „T"85. Andrew Gordon w swojej pracy poświęconej brytyjskiemu dowództwu w bitwie jutlandzkiej także mocno krytykuje Scheera, wyszczególniając jego trzy krytyczne błędy. Zdaniem tego autora każdy z nich mógł przyczynić się do zagłady Hochseeflotte, gdyby Niemcy mieli tamtego dnia mniej szczęścia. Za pierwszy błąd uznał zabranie przez Scheera 2 Eskadry (czyli pre-drednotów), której obecność nie powiększała siły bojowej Hochseeflotte, natomiast ograniczała jej szybkość i swobodę manewru. Za drugi błąd autor uważa bezrefleksyjne podążanie niemieckiej floty za zespołem Beatty'ego w czasie tzw. „wyścigu na północ” (Run to the North), chociaż kurs Brytyjczyków „sugerował coś więcej niż tylko chęć ucieczki”. Trzecim błędem był zaś drugi zwrot bojowy, prowadzący Hochseeflotte z powrotem pod ogień Grand Fleet, co całkowicie zniweczyło sukces pierwszego odwrotu ${ }^{86}$.

Kontradmirał Franz Hipper jest zazwyczaj przedstawiany w historiografii jako jeden z najzdolniejszych niemieckich dowódców I wojny światowej. Wśród historyków do dziś dominują zdecydowanie pozytywne opinie na jego temat. Niektórzy, jak na przykład Geoffrey Bennett, uznają go za najwybitniejszego dowódcę w dziejach niemieckiej marynarki wojennej ${ }^{87}$. Jego ówcześni przełożeni musieli mieć na jego temat również wysokie mniemanie, skoro w 1917 r. został następcą Scheera na stanowisku głównodowodzącego Hochseeflotte ${ }^{88}$. W przeciwieństwie do swojego przełożonego z bitwy jutlandzkiej oraz obydwu przeciwników Hipper raczej uniknął poważnej krytyki. Rzeczywiście, analizując przebieg bitwy można dojść do wniosku, iż nie popełnił żadnych znaczących błędów. Jednakże nie wykazał się też w jakiś wyjątkowo wybitny sposób. Realizował ustalony wcześniej plan, czyniąc to niezwykle skutecznie. Dowodząc 1 Grupą Rozpoznawczą, Hipper jako pierwszy wszedł w kontakt bojowy z brytyjskimi krążownikami liniowymi. Zdając sobie sprawę z przewagi liczebnej przeciwnika natychmiast zawrócił swój zespół, podążając za wytycznymi Scheera, aby naprowadzić Beatty’ego na główne siły niemieckie. Udało mu się to osiągnąć nie tylko bez strat wśród własnych okrętów, ale zatapiając dwa brytyjskie krążowniki liniowe. Ten sukces zawdzięczał jednak nie tyle swojemu dowodzeniu, ale umiejętnościom swoich załóg

\footnotetext{
85 A. Marder, From Dreadnought to Scapa Flow: the Royal Navy in the Fisher era 19041919, t. 3: Jutland and after May 1916 - December 1916, London 1966, s. 294.

86 A. Gordon, The rules of the game..., s. 121-122, 409, 458.

87 G. Bennett, Jutlandia..., s. 222.

88 C. London, Jutland..., s. 94.
} 
oraz przewadze technicznej ${ }^{89}$. Po połączeniu z siłami głównymi Hochseeflotte zespół Hippera szedł na czele niemieckiego szyku w czasie pościgu za Flotą Krążowników Liniowych. Nie udało mu się wykryć głównych sił Grand Fleet szykujących pułapkę na Niemców, częściowo z powodu słabej widoczności, częściowo przez zbieg okoliczności.

Jest to prawdopodobnie największy zarzut, jaki można mu postawić w związku z jego dowodzeniem w bitwie. Uwagę jego zespołu ściągnęła wymiana ognia z krążownikami liniowymi z 3 Eskadry kontradmirała Horace’a Hooda. Osiągnął kolejny duży sukces, zatapiając HMS Invincible, ale tym razem zapłacił za to poważniejszą cenę. Niemniej to właśnie pojawienie się na północny wschód (NE) od 1 Grupy Rozpoznawczej eskadry Hooda uniemożliwiło Hipperowi rozpoznanie głównych sił Grand Fleet, zmuszając go do zmiany kursu na południowo-wschodni (SE) ${ }^{90}$. Uszkodzenia $\mathrm{z}$ tego starcia doprowadziły do wyłączenia jego okrętu flagowego SMS Lützow z walki, a w dalszej perspektywie do jego zatopienia. Zmuszony przenieść swoją flagę na inny okręt, Hipper stracił kontrolę nad działaniami zespołu. $\mathrm{Z}$ powodu poważnych zniszczeń na innych niemieckich krążownikach liniowych trwało to wyjątkowo długo, dopiero po półtorej godzinie wszedł na pokład SMS Moltke ${ }^{91}$. W tym czasie bitwa trwała. Nie można zapominać, iż przez ten czas komendę nad 1 Grupą Rozpoznawczą sprawował w dramatycznych okolicznościach, komandor Johannes Hartog, dowódca

89 Okręty liniowe obydwu stron budowane były według nieco innych założeń, w związku z czym różniły się podstawowymi parametrami. Szczegółowy opis ich konstrukcji wychodzi poza ramy tego artykułu. Niemniej należy zaznaczyć, że okręty niemieckie pod kilkoma względami miały bezwzględną przewagę nad swoimi brytyjskimi odpowiednikami. Należały do nich: ochrona przeciwtorpedowa, pociski przeciwpancerne oraz ładunki miotające. Niemcy dysponowali działającymi pociskami przeciwpancernymi (APC) z zapalnikami opóźnionymi. Natomiast brytyjskie pociski przeciwpancerne okazały się bardzo zawodne, często eksplodując przy uderzeniu lub rozpadając się po trafieniu w pancerz. Duże znaczenie miała także różnica w składzie chemicznym ładunków miotających używanych przez obie strony. Brytyjski kordyt był mniej stabilny i przy kontakcie z ogniem eksplodował, co doprowadziło do zagłady trzech krążowników liniowych i dwóch krążowników pancernych. Natomiast niemieckie ładunki miotające nie wybuchały, tylko paliły się intensywnym płomieniem. Dlatego SMS Seydlitz pomimo trafienia w barbetę i zapaleniu się ładunków miotających ocalał, tracąc wieżę. Podobna sytuacja miała miejsce na SMS Derfflinger; zob. M. Stille, British Battlecruisers..., s. 24-25.

$90 \quad 3$ Eskadra Krążowników Liniowych wysłana przez Jellicoe, aby wesprzeć Beatty’ego, znalazła się za bardzo na wschód od miejsca głównego starcia z powodu błędnych informacji o pozycjach sił sojuszniczych i przeciwnika. Jednakże dzięki temu, włączając się do walki z niemieckimi krążownikami liniowymi, zmusiła je do zwrotu, nieco przypadkiem uniemożliwiając Hipperowi wykrycie głównych sił Grand Fleet; zob. A. Gordon, The rules of the game..., s. 431.

${ }_{91}$ M. Stille, British Battlecruisers..., s. 72, Uszkodzenie radia na SMS Moltke sprawiało, że kierowanie eskadrą przez Hippera było nadal utrudnione; zob. E. M. Raeder, Moje życie, Gdańsk 2001, s. 104-105. 
SMS Derfflinger łącznie z „szarżą śmierci” ${ }^{2}$. Po ostatnim starciu z siłami Beatty’ego tuż przed zachodem słońca krążowniki liniowe Hippera nie nadawały się do dalszej walki. Nie jest to zarzut pod adresem ich dowódcy. Wypełniły one tego dnia swoje zadanie $\mathrm{z}$ nawiązką. Za każdym razem, gdy ściągały na siebie ogień floty przeciwnika, oznaczało to, że odciągały go od pancerników Scheera. Można mieć tylko wątpliwości, czy takie użycie krążowników liniowych pokrywało się z założeniami, według których były budowane. To jest jednak zarzut raczej pod adresem głównodowodzącego Hochseeflotte.

Po zmroku Hipperowi pozostało poprowadzić swoje postrzelane okręty z powrotem do baz. 1 Grupa Rozpoznawcza podzieliła się i poszczególne okręty samodzielnie pokonywały drogę powrotną do ujścia rzeki Jade. Była to ryzykowna decyzja, chociaż można ją zrozumieć. Różny stopień uszkodzeń okrętów oznaczał, iż miałyby problem z utrzymaniem szyku, a przy napotkaniu przeciwnika wszystkie mogły paść jego ofiarą. Ryzyko się opłaciło, chociaż Niemcy mieli też dużo szczęścia z powodu problemów z komunikacją wśród Brytyjczyków. Niemniej udało się uratować wszystkie krążowniki liniowe z wyjątkiem SMS Lützow. Niewątpliwie Hipper spisał się w czasie bitwy bardzo dobrze - jej ciężar spoczął głównie na jego okrętach ${ }^{93}$.

Oceniając niemieckie rozpoznanie w czasie bitwy jutlandzkiej, należy pamiętać o jednej istotnej rzeczy. Niemcy nie mieli wystarczającej liczby nowoczesnych lekkich krążowników, aby móc pozwolić sobie na prowadzenie zbyt dalekiego zwiadu lub posyłanie ich do zbyt ryzykownych akcji. Hochseeflotte dysponowała zaledwie 11 jednostkami tej klasy w porównaniu z aż 26 brytyjskimi. Dodatkowo aż pięć z niemieckich krążowników lekkich, wchodzących w skład 4 Grupy Rozpoznawczej, było mocno przestarzałych. Rozwijały niewiele większą prędkość od nowych niemieckich drednotów, zaś mniejszą od krążowników liniowych. Ich możliwości prowadzenia zwiadu były więc iluzoryczne ${ }^{94}$. Scheer musiał polegać na zespole Hippera w kwestii informacji o przeciwniku. Ten zaś miał do dyspozycji tylko cztery nowoczesne lekkie krążowniki 2 Grupy Rozpoznawczej kontradmirała Friedricha Boedickera. W tej sytuacji trudno stawiać dowódcom niemieckich sił krążowniczych zarzuty w związku z niewykryciem na czas głównych sił Grand Fleet. Zwłaszcza że w kilku przypadkach, gdy kadm. von Reuter i kadm. Boedicker oddalali się zbytnio od swoich sił głównych, napotykali brytyjskie eskadry krążowników

\footnotetext{
92 Atak niemieckich krążowników liniowych w celu osłony odwrotu Hochseeflotte zyskał w literaturze miano „szarży śmierci” (niem. Todesritt, ang. Death Ride); zob. J. Corbett, Naval Operations..., s. 277.

93 J. Brooks, The Battle..., s. 514-517.

94 G. Bennett, Jutlandia..., s. 237.
} 
lekkich. Brytyjczycy mieli przewagę nie tylko w ilości, ale i uzbrojeniu krążowników lekkich. Tylko cztery najnowocześniejsze okręty Boedickera miały armaty $150 \mathrm{~mm}$. Pozostałe uzbrojone były w armaty $105 \mathrm{~mm}$, podczas gdy standardowym uzbrojeniem wszystkich brytyjskich krążowników lekkich były armaty 6 -calowe $(152 \mathrm{~mm})^{95}$. Utrata aż czterech krążowników (w tym trzech nowoczesnych) w czasie starcia była więc dla Niemców bardzo bolesna i znacząco zredukowała i tak już ograniczone możliwości rozpoznawcze Hochseeflotte.

Podsumowując powyższe rozważania, należy stwierdzić, iż każda ze stron działała według własnej taktyki podporządkowanej ich odmiennym doktrynom użycia floty oraz strategii wojennej. Dowódcy obydwu flot trzymali się swoich założeń taktycznych wypracowanych przed bitwą i to $\mathrm{w}$ dużej mierze $\mathrm{z}$ tego powodu nie doszło do rozstrzygającego starcia, jakie chcieliby widzieć co bardziej zapalczywi oficerowie po obu stronach oraz niektórzy komentatorzy. Paradoksalnie, różne cele strategiczne obydwu flot doprowadziły do powstania planów operacyjnych i taktyki opierającej się na podobnych założeniach.

Przy próbie oceny wszystkich dowódców z bitwy jutlandzkiej należy pamiętać o jednej rzeczy. Owi ludzie prowadzili do boju dwie największe nowoczesne floty liniowe, jakie widział świat. Wzięli udział w bezprecedensowym starciu na ogromną skalę - jednej z największych bitew morskich w historii. Każdy z nich dźwigał na swoich barkach ogromną odpowiedzialność za losy powierzonej mu floty. Żaden z admirałów tej epoki, włączając w to admirałów Tōgō Heihachirō i Zinowija Rożestwienskiego dowodzących flotami w bitwie pod Cuszimą ${ }^{96}$, nie brał udziału w starciu na taką skalę. Podobnie żaden z ich poprzedników aż od wojen napoleońskich. Nie posiadali więc ani praktyki, ani nawet właściwych wzorców. To wszystko zaś w bardzo trudnych warunkach oraz przy braku wielu potrzebnych informacji. Musieli pokonać trudności, często wcześniej nieznane. Uwzględniając to wszystko, można mieć wątpliwości, czy co bardziej zapalczywi komentatorzy z pierwszych lat po bitwie nie przesadzali z krytyką.

\footnotetext{
95 J. Brooks, The Battle..., s. 152-154.

96 Bitwa pod Cuszimą, największa bitwa morska wojny rosyjsko-japońskiej, odbyła się 27-28 V 1905 r. w Cieśninie Cuszimskiej (między wyspami Cuszimą a Kiusiu. Było to największe starcie parowych flot bojowych przed I wojną światową. Japońską Połączoną Flotą (4 pancerniki, 8 krążowników pancernych, 15 krążowników pancernopokładowych) dowodził admirał Tōgō Heihachirō zaś rosyjską 2 Eskadrą Pacyfiku uformowaną z Floty Bałtyckiej (8 pancerników, 3 krążowniki pancerne, 5 krążowników pancernopokładowych). Zakończyło się decydującym zwycięstwem floty japońskiej; zob. P. Olender, Wojna rosyjsko-japońska 1904-1905. Działania na morzu, Kraków 2010.
} 


\section{Ordre de Bataille}

\section{Brytyjczycy - Grand Fleet ${ }^{97}$}

Flota Krążowników Liniowych ${ }^{98}$

\begin{tabular}{|l|l|}
\hline $\begin{array}{l}\text { Okręt Flagowy (OF) FKL (wadm. David } \\
\text { Beatty) }\end{array}$ & HMS Lion \\
\hline $\begin{array}{l}\text { 1 Eskadra Krążowników Liniowych } \\
\text { (kadm. Osmond Brock) }\end{array}$ & $\begin{array}{l}\text { HMS Princess Royal (OF), HMS Queen } \\
\text { Mary, HMS Tiger }\end{array}$ \\
\hline $\begin{array}{l}\text { 2 Eskadra Krążowników Liniowych } \\
\text { (kadm. Wiliam Pakenham) }\end{array}$ & HMS New Zealand (OF), HMS Indefatigable \\
\hline $\begin{array}{l}5 \text { Eskadra Pancerników } \\
\text { (kadm. Hugh Evan-Thomas) }\end{array}$ & $\begin{array}{l}\text { HMS Barham (OF), HMS Malaya, } \\
\text { HMS Valiant, HMS Warspite }\end{array}$ \\
\hline $\begin{array}{l}\text { 1 Eskadra Krążowników Lekkich } \\
\text { (kom. Edwyn Alexander-Sinclair) }\end{array}$ & $\begin{array}{l}\text { HMS Galatea (OF), HMS Cordelia, } \\
\text { HMS Inconstant, HMS Phaeton }\end{array}$ \\
\hline $\begin{array}{l}\text { 2 Eskadra Krążowników Lekkich } \\
\text { (kom. Wiliam Goodenough) }\end{array}$ & $\begin{array}{l}\text { HMS Southampton (OF), HMS Nottingham, } \\
\text { HMS Birmingham, HMS Dublin }\end{array}$ \\
\hline $\begin{array}{l}\text { 3 Eskadra Krążowników Lekkich } \\
\text { (kadm. Trevylyan Napier) }\end{array}$ & $\begin{array}{l}\text { HMS Falmouth (OF), HMS Birkenhead, } \\
\text { HMS Gloucester, HMS Yarmouth }\end{array}$ \\
\hline Niszczyciele & $\begin{array}{l}\text { 1 Flotylla Niszczycieli } \\
\text { Niszczycieli (połączone), 13 i Flotylla Niszczycieli }\end{array}$ \\
\hline
\end{tabular}

\section{Siły Główne}

\begin{tabular}{|l|l|}
\hline $\begin{array}{l}\text { 2 Eskadra Pancerników } \\
\text { (wadm. Martyn Jerram) }\end{array}$ & Okręt Flagowy HMS King George V \\
\hline 1 Dywizjon ${ }^{103}$ (wadm. Martyn Jerram) & $\begin{array}{l}\text { HMS King George V, HMS Ajax. } \\
\text { HMS Centurion, HMS Erin }\end{array}$ \\
\hline 2 Dywizjon (kadm. Arthur Levenson) & $\begin{array}{l}\text { HMS Orion (OF), HMS Monarch, } \\
\text { HMS Conqueror, HMS Thunderer }\end{array}$ \\
\hline $\begin{array}{l}\text { 4 Eskadra Pancerników } \\
\text { (wadm. Doveton Sturdee) }\end{array}$ & Okręt Flagowy HMS Benbow \\
\hline 3 Dywizjon (kadm. Alexander Duff) & $\begin{array}{l}\text { HMS Superb (OF), HMS Royal Oak, } \\
\text { HMS Canada }\end{array}$ \\
\hline 4 Dywizjon (wadm. Doveton Sturdee) & $\begin{array}{l}\text { HMS Benbow, HMS Bellerophon, } \\
\text { HMS Temeraire, HMS Vanguard }\end{array}$ \\
\hline
\end{tabular}

97 Kolejność wymienianych okrętów oraz eskadr odpowiada ich miejscu w szyku (w przypadku głównych sił Grand Fleet po rozwinięciu).

98 Battle Cruiser Fleet.

991 Battle Cruiser Squadron.

1005 Battle Squadron.

1011 Light Cruiser Squadron.

1021 Destroyer Flotilla.

1031 Division. 


\begin{tabular}{|l|l|}
\hline $\begin{array}{l}\text { Okręt Flagowy Grand Fleet } \\
\text { (adm. John Jellicoe) }\end{array}$ & $\begin{array}{l}\text { HMS Iron Duke (na czele 3 Dywizjonu, } \\
\text { formalnie nie należał do żadnej z eskadr) }\end{array}$ \\
\hline $\begin{array}{l}\text { 1 Eskadra Pancerników (wadm. Cecil } \\
\text { Burney) }\end{array}$ & Okręt Flagowy HMS Marlborough \\
\hline 5 Dywizjon (kadm. Ernest Gaunt) & $\begin{array}{l}\text { HMS Colossus (OF), HMS Collingwood, } \\
\text { HMS St. Vincent, HMS Neptune }\end{array}$ \\
\hline 6 Dywizjon (wadm. Cecil Burney) & $\begin{array}{l}\text { HMS Marlborough, HMS Revenge, } \\
\text { HMS Hercules, HMS Agincourt }\end{array}$ \\
\hline $\begin{array}{l}\text { 3 Eskadra Krążowników Liniowych } \\
\text { (kadm. Horace Hood) }\end{array}$ & $\begin{array}{l}\text { HMS Invincible (OF), HMS Inflexible, } \\
\text { HMS Indomitable }\end{array}$ \\
\hline $\begin{array}{l}\text { 1 Eskadra Krążowników } 104 \\
\text { (kadm. Robert Arbuthnot) }\end{array}$ & $\begin{array}{l}\text { HMS Defence (OF), HMS Warrior, } \\
\text { HMS Duke of Edinburgh, HMS Black Prince }\end{array}$ \\
\hline $\begin{array}{l}\text { 2 Eskadra Krążowników } \\
\text { (kadm. Herbert Heath) }\end{array}$ & $\begin{array}{l}\text { HMS Minotaur (OF), HMS Hampshire, } \\
\text { HMS Shannon, HMS Cochrane }\end{array}$ \\
\hline $\begin{array}{l}\text { 4 Eskadra Krążowników Lekkich } \\
\text { (kom. Charles Le Mesurier) }\end{array}$ & $\begin{array}{l}\text { HMS Calliope (OF), HMS Constance, } \\
\text { HMS Comus, HMS Caroline, HMS Royalist }\end{array}$ \\
\hline Niszczyciele (kom. James Hawksley) & $\begin{array}{l}\text { 4 Flotylla Niszczycieli, 11 Flotylla Niszczycieli, } \\
\text { 12 Flotytlla Niszczycieli }\end{array}$ \\
\hline Pozostałe & $\begin{array}{l}\text { Tender wodnosamolotów HMS Engadine, } \\
\text { stawiacz min HMS Abdiel }\end{array}$ \\
\hline
\end{tabular}

\section{Niemcy - Hochseeflotte}

\section{Siły rozpoznawcze}

\begin{tabular}{|l|l|}
\hline $\begin{array}{l}1 \text { Grupa Rozpoznawcza } \\
\text { (kadm. Franz Hipper) krążowniki liniowe }\end{array}$ & $\begin{array}{l}\text { SMS Lützow (OF), SMS Derfflinger, SMS } \\
\text { Seydlitz, SMS Moltke, SMS Von der Tann }\end{array}$ \\
\hline $\begin{array}{l}\text { 2 Grupa Rozpoznawcza (kadm. } \\
\text { Friedrich Boedicker) krążowniki lekkie }\end{array}$ & $\begin{array}{l}\text { SMS Frankfurt (OF), SMS Eling, SMS Pillau, } \\
\text { SMS Wiesbaden }\end{array}$ \\
\hline Niszczyciele & $\begin{array}{l}\text { Krążownik lekki SMS Regensburg } \\
\text { (OF dowódcy torpedowców), 2 Flotylla } \\
\text { Torpedowców }\end{array}$ \\
& 9 Flotylla Torpedowców \\
\hline
\end{tabular}

\section{Siły Główne}

\begin{tabular}{|l|l|}
\hline $\begin{array}{l}3 \text { Eskadra Pancerników } \\
\text { (kadm. Paul Behncke) }\end{array}$ & Okręt Flagowy SMS König \\
\hline 5 Dywizjon (kadm. Paul Behncke) & $\begin{array}{l}\text { SMS König, SMS Grossem Kurfürst, } \\
\text { SMS Kronprinz, SMS Markgraf }\end{array}$ \\
\hline
\end{tabular}

\footnotetext{
1041 Cruiser Squadron.

105 I Aufklärungsgruppe.

106 II Torpedoboots-Flotille.

107 III Geschwader.
} 


\begin{tabular}{|l|l|}
\hline 6 Dywizjon (kadm. Hermann Nordmann) & $\begin{array}{l}\text { SMS Kaiser (OF), SMS Prinzregent Luitpold, } \\
\text { SMS Kaiserin }\end{array}$ \\
\hline $\begin{array}{l}\text { Okręt Flagowy Hochseeflotte } \\
\text { (wadm. Reinhard Scheer) }\end{array}$ & $\begin{array}{l}\text { SMS Friedrich der Grosse (na czele I Eskadry, } \\
\text { ale bez formalnego przydziału) }\end{array}$ \\
\hline $\begin{array}{l}\text { 1 Eskadra Pancerników } \\
\text { (kadm. Ehrhard Schmidt) }\end{array}$ & Okręt Flagowy SMS Ostfriesland \\
\hline 1 Dywizjon (kadm. Ehrhard Schmidt) & $\begin{array}{l}\text { SMS Ostfriesland, SMS Thüringen, } \\
\text { SMS Helgoland, SMS Oldenburg }\end{array}$ \\
\hline 2 Dywizjon (kadm. Walter Engelhardt) & $\begin{array}{l}\text { SMS Posen (OF), SMS Rheinland, } \\
\text { SMS Nassau, SMS Westfalen }\end{array}$ \\
\hline $\begin{array}{l}\text { 2 Eskadra Pancerników } \\
\text { (kadm. Franz Mauve) }\end{array}$ & Okręt Flagowy SMS Deutschland \\
\hline 3 Dywizjon (kadm. Franz Mauve) & $\begin{array}{l}\text { SMS Deutschland, SMS Hessen, } \\
\text { SMS Pommern }\end{array}$ \\
\hline $\begin{array}{l}\text { 4 Dywizjon (kadm. Gottfried Freiherr } \\
\text { von Dalwigk zu Lichtenfels) }\end{array}$ & $\begin{array}{l}\text { SMS Hannover (OF), SMS Schlesien, } \\
\text { SMS Schleswig-Holstein }\end{array}$ \\
\hline $\begin{array}{l}\text { 4 Grupa Rozpoznawcza } \\
\text { (kadm. Ludwig von Reuter) }\end{array}$ & $\begin{array}{l}\text { SMS Stettin (OF), SMS München, } \\
\text { SMS Frauenlob, SMS Stuttgart, } \\
\text { SMS Hamburg }\end{array}$ \\
\hline Niszczyciele & $\begin{array}{l}\text { Krążownik lekki SMS Rostock } \\
\text { (OF dowódcy torpedowców), 1 Flotylla } \\
\text { Torpedowców, 3 Flotylla Torpedowców, } \\
\text { 5 Flotylla Torpedowców, 7 Flotylla } \\
\text { Torpedowców }\end{array}$ \\
\hline & \\
\hline
\end{tabular}

\section{Bibliografia}

\section{Literatura}

Bacon R., The Jutland Scandal, London 1925.

Battle of Jutland $30^{\text {th }}$ May to $1^{\text {st }}$ June 1916. Official Despaches with Appendices, London 1920.

Beckett IF.W.., The Great War 1914-1918, Second Edition London 2007.

Bellairs C., The Battle of Jutland; The Sowing and the Reaping, London 1919.

Bennet G., Jutlandia 1916: Bitwa morska, Warszawa 2010.

Brooks J., The Battle of Jutland, Cambridge 2016.

Campbell N.J.M., Jutland: An Analysis of the Fighting, New York 2000.

Churchill W., The Worlds Crisis 1911-1918, London 2007.

Churchill W., The Worlds Crisis 1916-1918, t. 2, London 1927.

Corbett J., Naval Operations, t. 3, Londyn 1923.

Corbett J., Some principles of Maritime Strategy, Londyn 1911.

Flisowski Z., Bitwa jutlandzka 1916, Warszawa 1994.

Gibson L., Harper J., The Riddle of Jutland: An Authentic History, New York 1934.

Gill C. C., What happened at Jutland. The tactics of battle, New York 1921.

Gordon A., The rules of the game. Jutland and British Naval Command, New York 2013. 
Gozdawa-Gołębiowski J., Wywerka Prekurat T., Pierwsza wojna światowa na morzu, Warszawa 1997.

Harper J., Bacon R., The Jutland Scandal, The Truth about the First World War's Greatest Sea Battle, New York 2016.

Harper J., The Truth about Jutland, London 1927.

Hughes W., Fleet Tactics and Coastal Combat, Annapolis 2000.

Jellicoe J., The Grand Fleet 1914-1916. The creation, development and work, New York 1919.

Jellicoe N., Jutland: The Unfinished Battle; A Personal History of a Naval Controversy, Annapolis 2016.

Klimczyk T., Historia pancernika, Warszawa 1994.

Klimczyk T., Największe starcie pancerników. Bitwa Jutlandzka, Warszawa 2007.

London Ch., Jutland 1916 Clash of the Dreadnoughts, Botley - Oxford 2000.

Marder A., From Dreadnought to Scapa Flow: the Royal Navy in the Fisher era 19041919, t. 3: Jutland and after May 1916 - December 1916, Londyn 1966.

Massie R. K., Stalowe fortece, Nowy York 2014.

Schliehauf W., Jutland: The Naval Staff Appreciation, Barnsley 2016.

Staff G., German Battleships 1914-1918, Botley - Oxford 2009.

Stille M., British Battlecruisers vs German Battlecruisers 1914-1916, Botley - Oxford 2013.

\section{Materiały internetowe}

Grand Fleet Battle Orders, 1915, 1916, Jellicoe Papers, t. XXIII, British Library. http:// www.bl.uk/manuscripts/FullDisplay.aspx?ref=Add_MS_49011 (dostęp 17 VII 2019).

http://www.navweaps.com (dostęp 12 VII 2019).

http://www.bl.uk/manuscripts/ (dostęp 17 VII 2019).

\section{STRESZCZENIE}

\section{Marcin Kaczkowski, Problem oceny taktyki i dowodzenia w bitwie jutlandzkiej (1916)}

Niniejszy artykuł stanowi próbę przeanalizowania dowodzenia oraz taktyki zastosowanej w bitwie jutlandzkiej (1916), największej bitwie parowych okrętów liniowych w historii. Autor rozpoczyna stwierdzeniem, iż wokół wielu zagadnień związanych z bitwą jutlandzką istnieje wciąż sporo kontrowersji i przez ostatnie 100 lat toczyły się liczne dyskusje pomiędzy badaczami tematu. Jednym z takich zagadnień jest problem postępowania najważniejszych dowódców obu walczących stron. Artykuł podzielony jest na część poświęconą Brytyjczykom, w której zanalizowana została postawa admirała Johna Jellicoe głównodowodzącego Grand Fleet i wiceadmirała Davida Beatty, jak również kwestia rozpoznania. Druga część dotyczy Niemców: głównodowodzącego Hochseeflotte wiceadmirała Reinharda Scheera oraz kontradmirała Franza Hippera. 
Autor stara się na podstawie dostępnych dziś materiałów ocenić słuszność poszczególnych decyzji każdego z wymienionych admirałów oraz możliwe alternatywy, biorąc pod uwagę wszystkie uwarunkowania i niedogodności, z jakimi musieli się mierzyć.

Słowa kluczowe: bitwa jutlandzka, I wojna światowa, wojna na morzu, dowodzenie, Grand Fleet, Hochseeflotte, John Jellicoe, David Beatty, Reinhard Scheer, Franz Hipper

\section{SUMMARY}

\section{Marcin Kaczkowski, The problem of evaluation of the tactics and command in the battle of Jutland (1916)}

This article is an attempt to analyze the command and tactics used in the battle of Jutland (1916), the largest battle of steam ships of the line in history. The author begins by stating that there is still a lot of controversy around many issues related to the battle of Jutland, and for the last hundred years there have been numerous discussions between the researchers of this subject. One such issue is the problem of the behavior of the most important commanders of both fighting parties. The article is divided into a section devoted to the British, which analyses the conduct of Admiral John Jellicoe, Commander-in-Chief of the Grand Fleet and Vice Admiral David Beatty, as well as the issue of scouting. The second part concerns the Germans: Commander-in-Chief of the High Seas Fleet (Hochseeflotte) Vice Admiral Reinhard Scheer and Counter Admiral Franz Hipper.

Basing on materials available today, the author attempts to assess the justifiability of the individual decisions of each of the admirals and the possible alternatives, taking into account all the conditions and inconveniences they had to face.

Keywords: battle of Jutland, World War I, sea war, command, Grand Fleet, Hochseeflotte, John Jellicoe, David Beatty, Reinhard Scheer, Franz Hipper

\section{PEЗЮME}

\section{Марчин Качковский, Проблема оценки тактики и командования в Ютландском сражении (1916 г.)}

Данная статья представляет собой попытку анализа управления и тактики, используемой в Ютландском сражении (1916 г.) - самой крупной битве с участием паровых линейных кораблей в истории. Автор начинает статью с утверждения, согласно которому по многим вопросам, связанным с Ютландским сражением, до сих пор существует множество противоречий, а в течение последних сто лет среди ученых велось множество дискуссий на эту тему. Один из таких вопросов - поведение самых важных командиров 
обеих воюющих сторон. Первая часть статьи посвящена британцам; в ней проанализирована позиция адмирала Джона Джеллико, главнокомандующего Гранд-Флита, и вице-адмирала Дэвида Битти, а также вопрос военной разведки. Вторая часть посвящена немцам: главнокомандующему флота открытого моря вице-адмиралу Рейнхарду Шееру и контр-адмиралу Францу фон Хипперу.

На основе доступных сегодня материалов автор производит попытку оценить правильность индивидуальных решений каждого из перечисленных адмиралов, а также возможные альтернативы их действий с учетом всех условий и неудобств, с которыми им пришлось столкнуться.

Ключевые слова: Ютландское сражение, Первая мировая война, война на море, командование, Гранд-Флит, флот открытого моря, Джон Джеллико, Дэвид Битти, Рейнхард Шеер, Франц фон Хиппер 